\title{
A HETEROGENEIDADE DOS INSTRUMENTOS DE FLEXIBILIDADE ORÇAMENTÁRIA
}

Se o propósito específico desse trabalho é identificar dessemelhanças de estruturação normativa entre os instrumentos de flexibilidade da execução orçamentária, convém iniciar sua análise jurídica a partir de uma distinção que leva em conta o grau de participação do Poder Legislativo em sua aprovação. Há, assim, instrumentos de flexibilidade em que a intensidade da participação parlamentar é potencialmente:

a) Forte: créditos suplementares que ultrapassam os limites de autorização prévia da lei orçamentária; créditos especiais; transferências, transposições e remanejamentos.

b) Fraca: créditos suplementares abertos dentro dos limites de autorização prévia da lei orçamentária; créditos extraordinários.

c) Fraquissima: limitação de empenho e movimentação financeira.

Chama-se aqui de forte a aprovação de medidas de flexibilização da execução que dependem de aprovação prévia e específica do Poder Legislativo. De outra parte, essas medidas são, para os propósitos desta obra, consideradas fracas se a aprovação parlamentar ou não é prévia, como no caso dos créditos extraordinários, ou não é específica, como no caso dos créditos suplementares cuja abertura é previamente autorizada pela lei orçamentária anual. Há, ainda, os instrumentos de flexibilidade em que não há, ainda que pudesse haver, participação parlamentar, como a limitação de empenho e movimentação financeira. ${ }^{192}$

192 Optou-se aqui pela denominação que a legislação dá a cada uma destes casos, ainda que o uso 
Se a execução orçamentária tem por finalidade cumprir os objetivos da lei orçamentária aprovada pelo Poder Legislativo, seria de se supor que a utilização de instrumentos de flexibilidade por parte do Poder Executivo tivesse igualmente que se submeter, por paralelismo, à aprovação do parlamento. Há casos, conforme exposto nessa classificação, que escapam a tais fundamentos da execução orçamentária, com insuficiente controle parlamentar. Esses instrumentos serão caracterizados a seguir.

\subsection{CONTROLE PARLAMENTAR FORTE}

Conforme exposto anteriormente, o tópico se dedicará aos mecanismos de aprovação de algumas modalidades de créditos adicionais, bem como alguns outros instrumentos de menor relevância. Sob um mesmo gênero de créditos adicionais, portanto, se encontram formas variadas de exercício de controle parlamentar. As considerações inicialmente feitas sobre créditos adicionais não devem, desse modo, implicar que haja alguma uniformidade entre tais créditos. Será procedida unicamente com o propósito de delimitar melhor suas espécies para partir às distinçōes necessárias.

\subsubsection{Créditos adicionais suplementares e especiais}

Uma das alternativas possíveis para modificar o orçamento seria alterá-lo em bloco, no curso do próprio exercício financeiro. Tais orçamentos retificativos são instrumentos adicionais à realização da transparência. Essa vantagem, entretanto, é acompanhada de outras desvantagens que surgem principalmente do fato de que a elaboração de um orçamento retificativo no curso da execução orçamentária faz com que o orçamento original não seja levado suficientemente a sério pelo Executivo e o Legislativo. O governo, ao apresentar o projeto de orçamento, pode sentir-se livre da pressão de realizar estimativas precisas, contando com a possibilidade de realizar as correçôes posteriormente, e o corpo legislativo encarregado de aprová-lo terá incentivos para dedicar à atividade de apreciação da proposta orçamentária apenas uma atenção superficial.

Se os orçamentos retificativos originalmente servem para garantir o princípio da especialidade quantitativa do orçamento, assim como o fazem os créditos adicionais regularmente aprovados, e se têm a virtude de não afetar a unidade e a transparência orçamentárias, muitos países decidiram evitar os efeitos negativos de

do jargão político ou jornalístico pudesse facilitar a compreensão. Estes termos, porém, serão introduzidos nos itens respectivos. 
leis orçamentárias de retificação. Para isso, é comum que os Estados que adotam esse sistema façam com que o orçamento retificativo substitua o orçamento inicial não in toto, mas apenas o complete.

Tais orçamentos retificativos não estão previstos no Brasil, que preferiu adotar um sistema de alteraçôes específicas, principalmente por meio de créditos adicionais. Em muitos casos, porém, a distinção não é tão clara, visto que um mesmo ato normativo de abertura de crédito adicional contém alterações de inúmeras dotações orçamentárias.

As referências históricas aos créditos adicionais não são elogiosas. Frequentemente foram apontados como os piores inimigos do equilíbrio orçamentário, em razão do abuso em sua utilização. A legislação do Império procurou, em diversos momentos, reduzir a competência do Executivo em seu uso e houve caso de ministro que aconselhasse sua extinção. ${ }^{193}$

Foi a lei de 9 de setembro de 1850 a primeira a regular o uso de créditos adicionais. Antes desse diploma, sua abertura não era autorizada sequer no caso de ausência de parlamento. A prática, contudo, destoava da previsão jurídica. Para o exercício de 1828, o governo pediu suplementação de despesas destinadas à Corte do Rio de Janeiro (o único orçamento que havia sido votado pelo parlamento até 1830) e sofreu, por isso, forte oposição entre os políticos e juristas da época, pois essa seria a medida "capaz de inutilizar o orçamento, a principal arma do povo contra os excessos do poder" ${ }^{194} \mathrm{O}$ art. $4^{\text {o }}$ da lei regulamentadora dispunha, então, que os créditos suplementares poderiam ser abertos apenas para atender a despesas variáveis e flutuantes, devendo o ministro da Fazenda juntar à proposta de orçamento da despesa uma tabela com a nomenclatura dos serviços suplementáveis. Esse anexo ao orçamento anual ficou conhecido como Tabela $B$, forma pela qual ela será adiante referida. A Tabela $\mathrm{B}$, antecedente histórico das atuais margens de remanejamento, acompanhava o orçamento com a enumeração das dotações para as quais o governo poderia abrir créditos suplementares. Além disso, a lei de 1850 estabeleceu que os créditos suplementares somente poderiam ser utilizados pelo Executivo enquanto as câmaras não estivessem funcionando e no caso de despesa tão urgente que não pudesse esperar nova reunião do parlamento.

193 Cf. extensa referência ao tema em ROURE, A. Formação do direito orçamentário brasileiro. Rio de Janeiro: Jornal do Commercio, 1916.

194 VEIGA FILHO, J. Manual da sciencia das finanças. 3. ed. São Paulo: Secção de Obras d'O Estado, 1917, p. 287. 
Algumas leis orçamentárias posteriores ${ }^{195}$ trouxeram, também, uma limitação temporal, que se tornou tradicional nas legislações do período e que constitui prática relativamente incomum no direito orçamentário estrangeiro, que é a limitação temporal de abertura de crédito adicional. Nenhum crédito suplementar poderia ser aberto antes do nono mês do exercício financeiro, como uma medida para que o governo se cingisse às dotações orçamentárias aprovadas e tivesse que ao menos esperar que as consequências de deficiências na arrecadação efetivamente se sentissem antes de modificar o orçamento. Ademais, previram um limite quantitativo de 4 mil contos às suplementações.

A República manteve, inicialmente, a exigência de que se esperasse até o nono mês para modificar os créditos orçamentários. $\mathrm{Na}$ verdade, criou ainda uma condição: a de que o presidente do Tribunal de Contas se manifestasse sobre a legalidade da proposta de crédito suplementar (lei de 12 de dezembro de 1892). As manifestações do presidente do Tribunal de Contas, porém, acabaram por se dar no sentido de que a abertura de créditos poderia ocorrer em qualquer mês.

A apreciação desse tema sempre foi crítica, tanto na doutrina como em setores do meio político. Em 1862, o visconde do Rio Branco, ministro da Fazenda, afirmou que os créditos suplementares poderiam ser dispensados ou reduzidos se os serviços fossem convenientemente dotados. Apontou que o que impulsionava o alto volume de modificações no orçamento era a falta de sinceridade orçamentária. Nessa esteira, outro ministro da Fazenda, Silveira Martins, organizou proposta supressora da malfadada Tabela B, que "concorria para alterar os orçamentos e nulificar a fiscalização do Parlamento". ${ }^{196}$ Nessa ocasiāo, Silveira Martins defendeu as prerrogativas do parlamento, em um movimento contrário ao que posteriormente se verificaria de concentração de poderes orçamentários no Executivo.

Os créditos suplementares não funcionaram senão como um corolário da falta de transparência, clareza e sinceridade da proposta orçamentária, notando-se seu crescimento constante ao longo do tempo. Tudo em razão de verbas insuficientemente dotadas, despesas irrefletidamente cortadas pelo parlamento, ou propostas fictícias elaboradas pela administração. Problema ainda grave se tornou outra tabela, a Tabela A: contendo a relação dos créditos suplementares abertos no exercício anterior, servia de base para a elaboração da Tabela B, em um processo incremental que pouco observava as características conjunturais que efetivamente demandavam

195 Leis de 9 de setembro de 1962, de 20 de outubro de 1877, de 30 de outubro de 1882 e de 3 de setembro de 1884 .

196 SILVEIRA MARTINS apud ROURE, cit., p. 167-168. 
alterações orçamentárias. O procedimento supunha descaso com a importância do orçamento público. Verificou-se, igualmente, que os créditos suplementares funcionavam, nesse ciclo de incrementalismo, como motor do aumento das despesas, em razão do impacto que tinham em orçamentos futuros. Não eram os únicos responsáveis, é verdade; para isso concorriam também os créditos extraordinários, criados para os serviços novos.

As tentativas de limitação dessa conduta vieram expressas em importantes documentos do direito orçamentário do início do período republicano, nomeadamente o Projeto do Código de Contabilidade de Didimo da Veiga, de 1903, apresentado como substitutivo ao projeto de Código do deputado Alfredo Varela. Apontavam-se como casos justificadores da suplementação aqueles em que:

a) As rubricas orçamentárias não fossem suficientes para prover às despesas a que se destinavam.

b) Houvesse inadiável necessidade.

c) A rubrica estivesse compreendida na tabela de verbas suplementáveis (Tabela B).

d) A cifra não excedesse a 8 mil contos durante o exercício.

e) A utilização do crédito suplementar não importasse ampliação do serviço dotado no orçamento.

f) Houvesse manifestação do presidente do Tribunal de Contas por sua legalidade.

g) O Congresso não estivesse reunido.

Nota-se, aí, a exclusão do limite temporal do nono mês para o pedido do crédito. O Projeto de Didimo da Veiga tinha, nesse aspecto, poucas diferenças do anterior, do deputado Alfredo Varela: este, diferentemente daquele, apontava a necessidade de prévio assentimento do ministro da Fazenda, determinava a observância do prazo de nove meses e traçava limite quantitativo de 2 mil contos (ampliado para 10 mil em caso de guerra).

O conjunto desses expedientes teve suas consequências expressas por Agenor de Roure: "o perigo e o mal do crédito suplementar está exatamente nisto - na certeza que tem o Executivo de ver atendidos os seus pedidos de suplementação de créditos para verbas fixas, originando abusos na aplicação dos dinheiros públicos." ${ }^{197}$ Para promover um equilíbrio orçamentário fictício na proposta orçamentária, recorria-se

197 ROURE, cit., p. 172. 
às alteraçôes da lei, criando volume tal de créditos adicionais que se falava em "orçamento paralelo". Sendo, porém, utópico esperar que um governo administre sem recorrer a créditos adicionais, o desafio seria extinguir a "mentira orçamentária". ${ }^{198}$

Parece ainda prevalecer a certeza do Executivo de ver aprovadas suas propostas de créditos adicionais. Esse traço político do sistema orçamentário brasileiro contrasta com amplas prerrogativas parlamentares conferidas no plano constitucional para o exame e aprovação de sua abertura.

\subsubsection{Classificação}

Há três tipos de créditos adicionais: suplementares, especiais e extraordinários.

Suplementares são aqueles abertos para o reforço de dotações orçamentárias que, ao longo da execução, se mostraram insuficientes. Na dicção simples do art. 41, I, da Lei n. 4.320/64, são créditos suplementares os "destinados a reforço de dotação orçamentária". Suprem as deficiências de créditos orçamentários, mas também de créditos especiais, se a lei que os autorizou contiver autorização expressa nesse sentido.

Rigorosamente, a suplementação não é dos programas orçamentários em si, mas dos recursos financeiros que os atenderão. Nesse sentido, considerando-se que cada programa é o resultado de uma decisão política aprovada pelo parlamento, melhor seria que não fosse possí $\bullet$ vel a anulação de um programa para o reforço de outro, mas tão somente a anulação de determinados objetos de custo de cada programa, transferindo-se seus recursos para outra categoria prioritária. Isso em um cenário de orçamento-programa tecnicamente adequado.

A seu turno, créditos especiais são aqueles que atendem a despesas que não tenham dotação orçamentária específica (art. 41, II, Lei n. 4.320/64). São abertos para um novo programa, projeto ou atividade, servindo para destinar-lhe os recursos para finalidades tais como pessoal, material e outras, que possibilitarão a concretização de seu produto, e também para a despesa propriamente dita. Dessa forma, presta-se essa espécie ao aprimoramento do planejamento estatal inicialmente realizado.

Ainda, conforme o art. 167, $\$ 1^{\circ}$, da Constituição Federal, se o programa tiver duração superior a um exercício financeiro, é necessária a inclusão deste crédito no Plano Plurianual, por lei específica, sob pena de crime de responsabilidade.

Os créditos extraordinários, de acordo com o art. 167, $₫ 3^{\circ}$ da Constituição, têm sua abertura admitida para atender a despesas imprevisíveis e urgentes, como

198 ROURE, cit., p. 172. 
as decorrentes de guerra, comoção interna ou calamidade pública. Como o processo legislativo de sua criação é diferente dos demais, serão tratados em tópico apartado. Isso porque, conquanto as três modalidades de crédito adicional atendem a despesas não previstas, o crédito extraordinário é cabível em relação a fatos imprevisíveis pelo texto constitucional. Isto é, aqueles que não podem ser previstos de acordo com os meios e as técnicas disponíveis, do que posteriormente se tratará. Ressalte-se que a Constituição fala em imprevisibilidade e urgência, sendo esses dois requisitos indispensáveis para caracterizar o caráter extraordinário da medida. Não basta, deste modo, que a situação seja urgente, porém pudesse ter sido prevista. Por esta razão, sua abertura é autorizada por meio de medida provisória.

\subsubsection{Recursos disponíveis}

Os recursos dos créditos suplementares e especiais devem ser indicados na lei que os autoriza. Além disso, "a abertura de créditos suplementares e especiais depende da existência de recursos disponíveis para ocorrer à despesa e será precedida de exposição justificativa" (art. 43, Lei n. 4.320/64).

Assinale-se que o caput do art. 43 da Lei n. 4.320/64 diz ser necessário haver recursos disponíveis. Isso significa que no momento de efetivação da despesa deve existir a possibilidade de serem dispostos pela administração. ${ }^{199} \mathrm{E}$, de acordo com o $\$ 1^{\circ}$ desse artigo, os recursos que atendam às finalidades do caput não podem estar comprometidos, pois, evidentemente, nesse caso não são recursos disponíveis. Assim, por recursos comprometidos, deve-se entender aqueles que em razão de contratos, convênios ou leis atenderão a despesas obrigatórias, tais como pessoal, amortizações de empréstimos, juros, inativos (aposentados) e pensionistas, bem como receitas vinculadas a caixas especiais (fundos especiais) institucionalizados para o atendimento de obrigações resultantes da execução de programas especiais de trabalho, que têm, assim, receitas e despesas comprometidas com os respectivos objetivos específicos. ${ }^{200}$

Os recursos que cobrirão os créditos adicionais, segundo os incisos do art. 43, $\$ 1$ o, são:

- O superávit financeiro apurado em balanço patrimonial do exercício anterior.

- Os provenientes de excesso de arrecadação.

- Os resultantes de anulação parcial ou total de dotações orçamentárias ou de créditos adicionais autorizados em lei.

199 MACHADO Jr.; REIS, cit., p. 114.

${ }^{200}$ MACHADO Jr.; REIS, cit., p. 114. 
- O produto de operações de crédito autorizadas, em forma que juridicamente possibilite ao Poder Executivo realizá-las.

Fica claro que estas espécies de recursos são numerus clausus, vedando-se que sejam apontados outros tipos.

\subsection{Superávit financeiro}

$\mathrm{O}$ art. $43, \$ 2^{\circ}$, da Lei n. 4.320/64 entende por superávit financeiro a diferença positiva entre o ativo financeiro e o passivo financeiro, conjugando-se, ainda, os saldos dos créditos adicionais transferidos e as operações de crédito a eles vinculadas.

Ativo financeiro e passivo financeiro são elementos constitutivos do patrimônio financeiro, devendo conjugar-se a eles os saldos de créditos adicionais transferidos e as operações de créditos vinculadas para que se possa apurar um superávit líquido. $\mathrm{O}$ art. 105, $\$ 1^{\circ}$, da Lei n. 4.320/64 define que o ativo financeiro é composto dos créditos e valores realizáveis independentemente de autorização orçamentária e os valores numerários, ao passo que o passivo financeiro (art. 105, $\$ 3^{\circ}$ ) compreenderá as dívidas fundadas e outros pagamentos independentes de autorização orçamentária. Havendo saldo nesse balanço, poderão os recursos ser utilizados para cobrir créditos adicionais.

A apuração da existência de superávit financeiro é feita com o balanço patrimonial, no dia 31 de dezembro de cada ano.

A Lei Complementar n. 101/2000, no art. $1^{\text {o }} \$ \$ 1^{\text {o }}$, estabelece como um de seus objetivos a busca do equilíbrio das contas públicas, portanto, uma compensação entre receitas e despesas. Também o art. 4º, I, a, dessa lei dispóe que a Lei de Diretrizes Orçamentárias trate do equilíbrio entre receitas e despesas. No geral, os recursos utilizados para abertura de créditos adicionais provêm de situaçôes que envolvem as receitas (por exemplo, excesso de arrecadação e operações de crédito), ou então a diminuição de outras despesas (anulação de dotaçôes). Aumenta-se, pois, a despesa, por meio de uma contrapartida da receita ou da diminuição de ouras despesas, mantendo-se o equilíbrio. Pode-se diagnosticar, entretanto, que aqueles créditos adicionais abertos com recursos do superávit financeiro autorizam novas despesas sem alterar as receitas. Por esse motivo, tais créditos poderiam comprometer a situação fiscal do governo, o que exige esforço adicional para demonstrar, na justificativa e na apreciação do projeto, que a utilização do superávit financeiro será suficiente para evitá-lo.

\subsection{Excesso de arrecadação}

Pelo art. 43, $₫ 3^{\circ}$, da Lei n. 4.320/64, "entende-se por excesso de arrecadação, para os fins deste artigo, o saldo positivo das diferenças, acumuladas mês a mês, entre 
a arrecadação prevista e a realizada, considerando-se, ainda, a tendência do exercício.” Exige-se, dessa forma, o acompanhamento do comportamento das receitas, evitando-se a má prática de subestimar a previsão das entradas justamente para obter mais facilmente este excesso. Os métodos dos órgãos encarregados da contabilidade devem ser criteriosos para que, ao apurar esse excesso, não seja ele distorcido. Cálculos subestimados ocasionam o déficit no final do exercício financeiro. ${ }^{201}$ Naturalmente que quanto mais aperfeiçoado o sistema de orçamento-programa, maior a tendência de que essa fonte de recursos tenha sua importância diminuída. ${ }^{202}$

Permite-se considerar, ainda, a "tendência do exercício" para apurar o excesso de arrecadação, o que deve ser entendido em consonância com o que dispõe o art. $4^{\circ}, \$ 1^{\circ}$, da Lei Complementar n. 101/2000, segundo o qual o Anexo de Metas Fiscais estabelecerá as metas anuais, em valores correntes e constantes, das receitas. De qualquer forma, não é possível vedar a utilização da tendência para apurar o excesso. Se assim não fosse, isto é, se fosse necessário o efetivo recebimento do excesso nos cofres do Tesouro, os créditos adicionais com esses recursos só poderiam ser abertos no final do exercício financeiro. Por outro lado, a justificativa da tendência do exercício requer maior cuidado na sua elaboração, demonstrando a possibilidade efetiva de sua ocorrência, não só em termos estatísticos, mas também se apreciando os vários fatores que podem influenciá-la.

Estabelece, ainda, o $\$ 4^{\circ}$ do art. 43, que, "para o fim de apurar os recursos utilizáveis, provenientes de excesso de arrecadação, deduzir-se-á a importância dos créditos extraordinários abertos no exercício.”

É importante a ressalva de que o excesso deve ser apurado no conjunto das receitas, e não com relação a uma delas, isoladamente. Se as demais receitas estão se comportando aquém do previsto, não faria sentido usar-se o excesso de apenas uma delas para abrir o crédito adicional.

\subsection{Anulação parcial ou total de dotações}

Se determinadas dotações são parcial ou totalmente anuladas, o recurso restante pode ser utilizado para modificar outras dotações, incrementando-as ou criando outras novas. Nesse caso, não há aumento da importância das despesas totais do orçamento, não sendo afetado, portanto, seu equilíbrio. Note-se que o art. $43, \S 1^{\circ}$, III, refere-se à possibilidade de utilização dos recursos da anulação de créditos orçamentários ou adicionais autorizados por lei. Não sendo o crédito extraordinário

201 GIACOMONI, J. cit., p. 274.

202 MACHADO Jr.; REIS, cit., p. 116. 
autorizado por lei, sua anulação não pode fazer com que seus recursos sejam usados para cobrir outros créditos adicionais.

A escolha das despesas que serão abandonadas, como uma escolha política, deve levar em consideração que de nada adianta anularem-se "dotações consignadas para despesas essenciais, somente com o fito de criar recursos. Seria cobrir um santo, descobrindo outro." 203

\subsection{Operações de crédito}

As operações de crédito compóem as receitas de capital (art. 11, $\$ 4^{\circ}$, da Lei n. 4.320/64, com redação dada pelo Decreto-lei n. 1.939/82). São operações rigorosamente controladas pela Lei de Responsabilidade Fiscal. Seu art. 29, III, as define como o "compromisso financeiro assumido em razão de mútuo, abertura de crédito, emissão e aceite de título, aquisição financiada de bens, recebimento antecipado de valores provenientes da venda a termo de bens e serviços, arrendamento mercantil e outras operações assemelhadas, inclusive com o uso de derivativos financeiros."

$\mathrm{O}$ art. 43, IV, da Lei n. 4.320/64 é expresso ao prescrever que os recursos provenientes de operações de crédito somente poderão ser utilizados para a abertura de créditos adicionais "em forma que juridicamente possibilite ao Poder Executivo realizá-las”, evitando-se a utilização de operações de crédito sem base legal, econômica ou financeira. Nesse sentido, é preciso que as operações de crédito sejam autorizadas de tal modo que os compromissos possam ser satisfeitos sem que o crédito público fique abalado.

Uma questão que se coloca é se o produto da operação de crédito precisa ter sido obtido no momento da abertura do crédito adicional. A respeito, o art. $7^{\circ}, \mathbb{S}$ $2^{\circ}$, da Lei n. 4.320/64, diz que "o produto estimado de operações de crédito e de alienação de bens imóveis somente se incluirá na receita quando umas e outras forem especificamente autorizadas pelo Poder Legislativo em forma que juridicamente possibilite ao Poder Executivo realizá-las no exercício."

Portanto, a operação deve ser viável e a realização possível no exercício, sucedendo-se naquele ano. Outros impedimentos, por exemplo, que inviabilizariam as operações de crédito, são aqueles trazidos pela Resolução n. 43/2001 do Senado Federal, a respeito do endividamento dos estados e municípios. A expectativa de recursos provenientes dessas operações inviáveis não ensejaria a abertura dos créditos adicionais, ainda que não se exija, categoricamente, que primeiro deve haver o recurso para depois abrir o crédito.

${ }^{203}$ MACHADO Jr.; REIS, cit., p. 115. 


\subsubsection{Compatibilidade dos créditos adicionais com as leis orçamentárias}

A necessária compatibilidade entre todas as leis orçamentárias e os créditos adicionais se destina a evitar a criação de orçamentos paralelos, alheios a um contexto de planejamento anterior e à decisiva manifestação da vontade parlamentar. A participação dos diferentes órgãos administrativos e legislativos se submete às determinações das leis orçamentárias, que geram efeitos na administração. A elaboração da proposta é decidida em diferentes níveis hierárquicos administrativos, que devem ter por norte a consecução da decisão expressa no plano de médio prazo (Plano Plurianual), nas diretrizes específicas para o orçamento (Lei de Diretrizes Orçamentárias) e na Lei Orçamentária Anual.

$\mathrm{Na}$ organização dos orçamentos públicos no Brasil, os programas orçamentários devem ser compatíveis com o Plano Plurianual (art. 165, $\$ 7$ o da Constituição). Com isso, pode haver interesse não apenas em alterar a lei orçamentária, mas também alguma das metas, objetivos ou diretrizes do próprio plano plurianual. Nesse caso não se tratará de crédito adicional, porque o PPA não quantifica dotações orçamentárias. É possível, contudo, que, em hipótese específica, a lei que abra crédito adicional preveja alteração do plano plurianual, além do fato de que uma alteração em algum dispositivo desse plano muito provavelmente acarretará a necessidade futura de alteração da lei orçamentária - e seja feita exclusivamente com tal propósito. Todas essas ações orçamentárias estão, portanto, mutuamente implicadas.

As leis que instituem os planos plurianuais costumam prever hipóteses de sua modificação, que pode acontecer pela via legislativa ou por decreto do chefe do Poder Executivo, nas hipóteses em que estabeleça. Sendo por lei, a alteração por ocorrer por duas vias principais: projeto de lei de revisão anual do plano ou lei específica, ambos de iniciativa do chefe do Poder Executivo. ${ }^{204}$ Está aí reconhecida a possibilidade de alteração em bloco ou caso a caso do Plano Plurianual.

$\mathrm{Na}$ hipótese de lei de revisão anual, sua proposta deve ser encaminhada ao congresso até o dia 31 de agosto e pode ter três finalidades distintas: incluir, alterar ou excluir um programa.

Para incluir um programa, tem-se tornado recorrente nos planos plurianuais a exigência de que haja diagnóstico sobre a situação do problema que se deseja enfrentar ou sobre a demanda da sociedade que se deseja atender e a indicação dos recursos que financiarão o programa proposto. Ao passo que, tratando-se de alteração ou exclusão, devem-se expor as razões que motivam a proposta.

204 Para exemplificar aquilo que, daqui por diante, for tratado sobre as alterações do PPA, cf. art. 15 da Lei n. 11.653, de 7 de abril de 2008 (PPA 2008-2011). 
É no caso de alteração e de inclusão de programa do PPA que as relações dessa lei com a dos créditos adicionais ficam mais claras. Por alteração entende-se: a modificação da denominação, do objetivo ou do público-alvo do programa; a inclusão ou exclusão de ações orçamentárias; e alteração do título, do produto e da unidade de medida das ações orçamentárias. Nessa última situação (alteração do título, do produto e da unidade de medida das ações orçamentárias), a lei orçamentária anual ou leis que abram créditos adicionais podem promover a modificação do programa do PPA, desde que não modifiquem a finalidade da ação ou sua abrangência geográfica e mantenham a mesma codificação ( $\$ 4^{\circ}$ do art. 15 da Lei n. 11.653, de 7 de abril de 2008). Por sua vez, a inclusão de um programa pode ser realizada mediante lei de abertura de crédito especial desde que ela apresente, em anexo específico, as informações referentes às projeçôes plurianuais e aos atributos constantes do Plano.

Fica o Poder Executivo autorizado, ainda, a modificar o PPA por ato próprio nos casos de:

- Alteração do órgão responsável por programas e ações.

- Alteração dos indicadores dos programas e seus respectivos índices.

- Inclusão, exclusão ou alteração de ações e respectivas metas, no caso de ações não orçamentárias.

- Adequação da meta física de ação orçamentária para compatibilizá-la com alterações no seu valor, produto, ou unidade de medida, efetivadas pelas leis orçamentárias anuais e seus créditos adicionais ou por leis que alterem o Plano Plurianual.

- Incorporação das alterações decorrentes da lei orçamentária; e incorporação da relação de obras inacabadas, observando as decisões do Tribunal de Contas da União sobre o assunto.

A LDO traz diretrizes específicas sobre as alterações orçamentárias, sendo as principais delas:

Se faz necessário informar o número de beneficiados nas respectivas metas quando for necessário incluir recursos na LOA e em seus créditos adicionais para atender a despesas com auxílio-alimentação ou refeição, assistência pré-escolar e assistência médica e odontológica, inclusive das entidades da administração indireta.

Os recursos aprovados na LOA e em seus créditos adicionais para contrapartida nacional de empréstimos internos e externos, bem como para o pagamento de amortização, juros e outros encargos, somente poderão ser remanejados para outras categorias de programação por meio da abertura de créditos adicionais propostos 
por intermédio de projetos de lei, com a exceção de poderem sê-lo por meio de decreto se estiverem contidos nos limites de créditos suplementares da LOA, desde que mantida a mesma finalidade.

Os recursos alocados na LOA, destinados ao pagamento de precatórios judiciários e de débitos judiciais periódicos vincendos e ao cumprimento de débitos judiciais transitados em julgado considerados de pequeno valor, incluídos os decorrentes dos juizados especiais federais, somente poderão ser cancelados para a abertura de créditos adicionais com outra finalidade mediante autorização específica do Congresso Nacional.

$\mathrm{Na}$ abertura de créditos extraordinários é vedada a criação de novo código e título para ação existente.

A reabertura dos créditos especiais e extraordinários, conforme disposto no art. $167, \$ 2^{\circ}$, da CF, será efetivada, se necessária, mediante ato próprio de cada Poder e do Ministério Público da União, até 31 de janeiro de 2011.

$\mathrm{Na}$ estimativa das receitas do projeto de lei orçamentária anual e da respectiva lei, poderão ser considerados os efeitos de propostas de alterações na legislação tributária e das contribuições, inclusive quando se tratar de desvinculação de receitas, que sejam objeto de proposta de emenda constitucional, de projeto de lei ou de medida provisória que esteja em tramitação no Congresso Nacional. Caso as alterações propostas não sejam aprovadas, ou o sejam parcialmente, até sessenta dias após a publicação da LOA, de forma a não permitir a integralização dos recursos esperados, as dotações à conta das referidas receitas serão canceladas, em função da aplicação de diferentes percentuais sobre determinadas dotações, mediante decreto, nos trinta dias subsequentes.

A elaboração e a execução da LOA 2011 e de seus créditos adicionais obedecerão aos princípios constitucionais da impessoalidade, da moralidade, da publicidade e da eficiência na administração pública, não podendo ser utilizadas para influir na apreciação de proposições legislativas em tramitação no Congresso Nacional. ${ }^{205}$

A Lei Orçamentária Anual, por sua vez, é mais diretamente afetada pela abertura de créditos adicionais, em razão de sua função específica de reforçar ou criar novos programas. Entretanto, em razão do art. $165, \$ 8^{\circ}$ da Constituição, não está vedada pelo princípio da exclusividade orçamentária a prévia autorização, na própria lei de orçamento, para abertura de créditos suplementares, nos limites percentuais que forem ali traçados. É o que se chama de margem de remanejamento - assunto

205 BRASIL. Ministério do Planejamento. Manual técnico orçamentário 2011. Brasília: Secretaria de Orçamento Federal, 2011 (5ª versão), p. 91-92. 
a ser mais explorado posteriormente. Os orçamentos anuais, corriqueiramente, dispõem que essa abertura, feita por decreto presidencial, no âmbito federal, é autorizada desde que as alteraçōes promovidas na programação orçamentária sejam compatíveis com a obtenção da meta de resultado primário estabelecida para o exercício fiscal referente, e que corram à conta dos recursos de excesso de arrecadação, estabelecendo destinações específicas. ${ }^{206}$

\subsubsection{Fases administrativa e legislativa dos créditos adicionais}

O estudo do processo orçamentário tende a levar em consideração, predominantemente, o processo legislativo orçamentário. Boa parte dele, porém, está propenso a se passar antes que as alterações sejam levadas ao Congresso Nacional e nos respectivos órgãos legislativos estaduais e municipais, pelo que é de grande relevância observar também a fase administrativa de elaboração das propostas de abertura de créditos adicionais.

Uma primeira distinção é, porém, fundamental. Os créditos adicionais alteram uma situação jurídica pré-existente: ou dão nova quantificação a créditos orçamentários anteriormente previstos, ou criam novos programas e açôes. Ou seja, trata-se da modificação de uma lei em vigor (a lei orçamentária anual). Desse modo, a fase legislativa dos créditos adicionais não se confunde com a fase legislativa dos créditos orçamentários, ainda que essa tenha grande influência sobre aquela (assim como o tem a lei de diretrizes orçamentárias), porque a regulamentação do procedimento de modificação do orçamento pelo órgão competente, no plano administrativo, tem como base a legislação orçamentária vigente. A fase administrativa dos créditos adicionais encontra-se entre essas duas fases legislativas, que não hão de confundir-se, tendo por fundamento a lei orçamentária naquele exercício financeiro vigente, com vistas a iniciar outro processo legislativo, agora distinto, para alterá-la.

Essa sequência de procedimentos significa que a abertura de créditos adicionais é um conjunto articulado de ações - e por isso mostra-se tarefa bastante complexa. Assim é que se torna possível falar aqui, verdadeiramente, em "processo" de criação de tais créditos, pois se trata de uma sequência encadeada de atos que se concluem com um resultado final. ${ }^{207}$ Esse resultado final é a elaboração do decreto de abertura de créditos suplementares, no caso daqueles previstos em prévia autorização da lei

${ }^{206}$ Cf. arts. $4^{\text {o e }} 5^{\circ}$ da Lei n. 12.214 de 26 de janeiro de 2010.

207 Utilizam-se aqui as noções sobre processo administrativo expostas por Celso Antônio Bandeira de Mello (Curso de direito administrativo. 26. ed. São Paulo: Malheiros, 2009, p. 480). 
orçamentária anual, de medida provisória sobre créditos extraordinários, ou de projeto de lei, apto a cada uma das espécies de créditos adicionais.

Ao ser iniciado o processo legislativo de abertura de crédito adicional, não se está diante de uma extensão ou prorrogação da fase de elaboração do orçamento. Essa se encerrou, seguindo os prazos constitucionais. A particularidade da aprovação dos créditos adicionais ocorre na fase de execução orçamentária, da qual o Poder Legislativo é chamado a participar. Conquanto a decisão parlamentar não seja de execução da despesa em si, mas de autorização para execução de determinada dotação acima dos montantes anteriormente previstos, trata-se de uma participação constitucionalmente indispensável. Isso por si só indica que o parlamento continua ativo durante a fase de execução, não havendo qualquer forma de hibernação entre as fases de aprovação e de controle, nas quais comumente as explicações sobre o ciclo orçamentário costumam restringir suas competências.

\subsection{Fase administrativa: alterações quantitativas e qualitativas}

Esta fase desenvolve-se, em um primeiro momento, em três planos: o órgão central, os órgãos setoriais e as unidades orçamentárias. ${ }^{208} \mathrm{O}$ órgão central é, na esfera federal, a Secretaria de Orçamento Federal (SOF) do Ministério do Planejamento, Orçamento e Gestão, e a matéria é normatizada anualmente em atos administrativos, que regulamentam os procedimentos e os prazos.

As alterações propostas podem ser qualitativas ou quantitativas. Serão qualitativas se envolverem a criação de um novo programa. Esta alteração significa o surgimento de uma nova ação, com a consequência de ser necessário um novo subtítulo no orçamento. A proposta dessa alteração pode partir tanto das unidades orçamentárias como dos órgãos setoriais ou da própria SOF. Caso não parta do órgão central (isto é, se provier das unidades orçamentárias ou dos órgãos setoriais), a solicitação deve seguir o procedimento explicado a seguir, no que couber: cada unidade menor encaminha-a à instância superior, que a apreciará nos limites de suas atribuições. No caso de alterações qualitativas, porém, as propostas federais não são encaminhadas apenas à SOF, mas também à Secretaria de Planejamento e Investimentos (SPI) do Ministério do Planejamento, Orçamento e Gestão. Se ambas então estiverem de acordo, o novo programa de trabalho será criado e disponibilizado no Sistema Integrado de Dados Orçamentários (Sidor) para, posteriormente, atender suas necessidades específicas.

${ }^{208}$ O mesmo foi observado por CONTI a respeito da fase administrativa de elaboração da lei orçamentária anual. Cf. CONTI, J. M. A autonomia financeira do poder judiciário. São Paulo: MP Editora, 2006, p. 77. 
Por serem quantitativas, tais alterações destinam-se a possibilitar a efetiva realização dos programas orçamentários por meio da alocação de recursos, cuja correta identificação é uma responsabilidade comum das unidades orçamentárias, dos órgãos setoriais e do órgão central. A primeira identificação da necessidade pode partir de qualquer um desses órgãos. Em qualquer caso, iniciando-se nas unidades orçamentárias ou nos órgãos setoriais, devem cumprir os objetivos, procedimentos e prazos estabelecidos nas Portarias da SOF, mediante acesso ao Sidor. Porém, caso a alteração quantitativa proceda a uma alteração qualitativa (isto é, se envolver a abertura de crédito especial ou extraordinário), é necessário utilizar, antes, o Processo de Proposta e Análise de Alteraçôes Orçamentárias, no qual será cadastrado o novo Programa de Trabalho e obtido seu código. ${ }^{209}$

Por sua vez, no menor dos três planos administrativos mencionados, as unidades orçamentárias desempenham importante papel na identificação de exigências de suplementação de verbas ou de criação de novas dotações orçamentárias porque são elas que fazem as primeiras solicitações. Elas veiculam, em seu âmbito, as necessidades ali presentes. São as menores unidades responsáveis pela administração de recursos públicos, às quais o orçamento designa verbas específicas para seus programas, ${ }^{210}$ ainda que não sejam as menores unidades administrativas. Revela-se, nessa tendência, um processo de elaboração administrativa das propostas de créditos adicionais "de baixo para cima".

A função que as unidades orçamentárias assumem é a de coordenação do processo de alterações orçamentárias no seu âmbito de atuação, articulando as necessidades das unidades administrativas que as compóem. ${ }^{211}$ As propostas apresentadas referem-se às alterações vistas como necessárias tanto em termos qualitativos (criando um novo programa) como quantitativos (viabilizando a execução de um programa existente).

Como é possível perceber, o início dessa fase se mostra complexo, pois cada uma das unidades orçamentárias terá realizado um longo trabalho de averiguação das necessidades em seu âmbito de atuação (a partir das requisições das unidades administrativas), cada uma delas estabelecendo as suas próprias diretrizes. O início dessa fase é, portanto, altamente atomizado e diversificado. Compete às unidades

209 BRASIL. Ministério do Planejamento. Manual técnico orçamentário 2011. Brasília: Secretaria de Orçamento Federal, 2011 (5a versão), p. 94-96.

210 É o que estatui o art. 14 da Lei n. 4.320/64, segundo o qual "constitui unidade orçamentária o agrupamento de serviços subordinados ao mesmo órgão ou repartição a que serão consignadas dotações próprias."

211 BRASIL. Ministério do Planejamento. Manual técnico orçamentário 2011, cit., p. 93. 
orçamentárias, além de fixar estas diretrizes, realizar estudos de adequação da estrutura programática do exercício. Igualmente, devem formalizar a sua proposta a ser enviada ao devido órgão setorial, coordenar o processo de atualização e aperfeiçoamento das informações constantes do cadastro de atualizações orçamentárias e analisar e validar as solicitaçôes das respectivas unidades administrativas. ${ }^{212}$

Mas essa tendência "de baixo para cima” não é absoluta porque as propostas elaboradas pelas unidades orçamentárias devem ser compatíveis com os objetivos de médio e longo prazo das demais leis orçamentárias. Em razão disso, costumam as portarias da SOF estabelecer uma tabela em que constam diversos tipos de alterações do orçamento, nos quais se identificam tanto o fundamento legal da alteração como a forma (a espécie normativa adequada) para sua abertura, além da fonte dos recursos. Esse processo de tipificação, que submete as alterações orçamentárias às determinações anteriormente feitas, com suas diretrizes especificadas, também permite identificar no processo administrativo dos créditos adicionais momentos "de cima para baixo", embora, até aí, esses funcionem apenas como um limite dentro do qual podem ser feitas livremente as sugestôes "de baixo para cima" ${ }^{213}$ Cabe, além disso, aos órgãos setoriais verificar a exatidão das informações que lhe são enviadas pelas unidades orçamentárias. ${ }^{214}$

Os órgãos setoriais têm funções bastante semelhantes àquelas das unidades orçamentárias, coordenando e articulando as propostas em seu âmbito, analisando-as e validando-as. Também estabelecem diretrizes, avaliam a adequação das alterações aos programas, formalizam ao órgão central do Ministério do Planejamento as propostas de sua área, coordenam e atualizam seu cadastro de programas e ações e definem suas instruções. ${ }^{215}$

Essa etapa do ciclo orçamentário é realizada por meio de sistema informatizado (o Sistema Integrado de Planejamento e Orçamento - SIOP), mediante o qual se encaminham as propostas, feitas por acesso online, ao órgão setorial do Sistema de Planejamento e de Orçamento Federal, ou equivalente, dos respectivos órgãos.

212 BRASIL. Ministério do Planejamento. Manual técnico orçamentário 2011, cit., p. 93-94.

213 Há outros momentos “de cima para baixo" na formação dos créditos adicionais, como quando, por exemplo, exigências conjunturais exigem alterações orçamentárias. O tema será desenvolvido, porém, em tópico específico, dispensando-se seu maior aclaramento nesta etapa.

214 Foram analisadas as seguintes Portarias da SOF: n. 7, de 1 de março de 2011; n. 2, de 12 de janeiro de 2009; n. 7, de 28 de março de 2008; n. 4, de 02 de fevereiro de 2007; n. 6, de 29 de maio de 2006; e n. 3, de 16 de março de 2005. Estas portarias, embora se renovem anualmente (afinal, as leis de diretrizes orçamentárias e as leis orçamentárias são anuais), costumam apresentar sempre teor semelhante, identificando-se aí a constância do método de encaminhamento das propostas de alteração orçamentária.

215 BRASIL. Ministério do Planejamento. Manual técnico orçamentário 2011, cit., p. 93. 
Os pedidos feitos pelas unidades orçamentárias interessadas são analisados pelos órgãos setoriais aos quais foram encaminhadas, que, então, avaliam globalmente a necessidade dos créditos solicitados e a possibilidade de compensação de recursos que serão utilizados em sua cobertura, incluindo-se essa análise na solicitação iniciada na unidade orçamentária.

Como já dito, as unidades orçamentárias devem enquadrar seus pedidos em uma das modalidades admitidas de créditos adicionais, de acordo com o art. $41 \mathrm{da}$ Lei n. 4.320/64 - suplementares, especiais ou extraordinários. Não há, porém, um processo legislativo comum para a abertura destes créditos, cada qual passível de ser introduzido no sistema jurídico por espécies normativas diferentes, conforme o caso: decretos, leis ou medidas provisórias. Esse tema será tratado com maior pormenorização em tópico posterior, mas nesta fase administrativa ele é relevante em razão dos prazos estabelecidos para os órgãos setoriais encaminharem as propostas ao órgão central.

Conforme o veículo introdutor admitido para cada tipo de crédito adicional, estabelece-se um prazo distinto para que os órgãos centrais enviem a consolidação de suas propostas ao órgão central. No exercício de seu poder de coordenação, os órgãos setoriais podem estabelecer prazos específicos para as unidades orçamentárias de seu âmbito. Ainda, as portarias da SOF que regulam a matéria não raro trazem prazos especiais para determinadas despesas. Entende-se que a dilatação do prazo seria necessária para despesas imprevistas que podem surgir em qualquer período do ano, e que não poderiam ser calculadas senão por grosseira estimativa, ou então outras despesas que não podem deixar de ser feitas por imposição legal. Admite-se, então, que os créditos adicionais previstos na LOA possam ser encaminhados até data bem próxima do final do exercício financeiro (comumente em fins de novembro), destinando-se, por exemplo, a despesas decorrentes de sentenças judiciais, de concessão de benefícios da seguridade social ou de encargos e despesas com pessoal. ${ }^{216}$ Ressalta-se que, a partir de 2008, a SOF passou a incluir nesses prazos especiais as despesas com anistiados políticos, dando mais flexibilidade à sua cobertura, que com habitualidade vê a abertura de créditos suplementares que a elas se destinam autorizada pelas sucessivas leis orçamentárias anuais nos limites da margem de remanejamento - mediante decreto, portanto.

O órgão central, além de definir as diretrizes para o processo de alterações orçamentárias, assume posição de comando, supervisão e orientação técnica dos

216 Cf. Portarias da SOF n. 7, de 1 de março de 2011; n. 2, de 12 de janeiro de 2009; n. 7, de 28 de março de 2008; n. 4, de 2 de fevereiro de 2007; n. 6, de 29 de maio de 2006; e n. 3, de 16 de março de 2005. 
órgãos setoriais e unidades orçamentárias. Compete-lhe, também, consolidar e formalizar as propostas de alteraçôes orçamentárias da União. Isso significa que a SOF prepara os atos destinados a abrir créditos adicionais. Esses atos podem ser decreto do Poder Executivo para os créditos suplementares previstos na lei orçamentária anual, projeto de lei para os créditos suplementares dependentes de autorização legislativa e para os créditos especiais, medida provisória para os créditos extraordinários e portaria da própria SOF quando se tratar de alteraçoes de fontes de recursos, de identificador de uso ou de identificador de resultado primário.

Nota-se, pois, que muitas as alteraçōes orçamentárias resolvem-se nessa fase administrativa, desde que contenham autorização legal para tanto.

A abertura de créditos suplementares por decreto do Poder Executivo se dá nos limites da autorização prevista na Lei Orçamentária Anual, com fundamento no art. 165, $\$ 8^{\circ}$ da Constituição. Uma apreciação crítica deste tópico será feita em item posterior, mas vê-se que os decretos preparados pela SOF ocupam grande parte das normas administrativas referentes a créditos adicionais. Nos limites traçados pela Lei n. 12.381, de 9 de fevereiro de 2011 (Orçamento para 2011), nota-se, por exemplo, que são 32 as modalidades de eventos (algumas das quais se desdobram em outras) cuja suplementação é autorizada por decreto do Executivo. Além daquelas incluídas na margem de remanejamento normalmente de 10\% (descrita como Tipo 100 nas Portarias da SOF), há outras tantas em que o limite é bem maior, tais como a autorização para anulação de até $50 \%$ das dotações de mesmo Grupo de Natureza de Despesa (GND), que podem ser dentro deste limite remanejadas, por exemplo, nas dotações do Instituto Nacional de Educação dos Surdos e do Colégio Pedro II (LOA 2011, art. 4º, XII, $a$, item 1).

Mas muitas dessas alterações sequer chegam a ser feitas pelo Presidente da República. Basta, para elas, portaria do Ministro do Planejamento ou do próprio Secretário do Orçamento Federal, o que mostra o grau de importância de órgãos do Executivo na execução orçamentária. Essas alterações, que não se incluem entre os créditos adicionais, destinam-se a alterar as fontes de financiamento do orçamento de investimento e as fontes de recursos, as modalidades de aplicação e os identificadores de uso e de resultado primário, as metas, os produtos, as unidades de medida e as esferas orçamentárias das ações constantes da lei de orçamento e dos créditos adicionais, inclusive os reabertos no exercício. $\mathrm{O}$ ato do Ministro do Planejamento, Orçamento e Gestão destina-se às alterações das fontes de recursos, indicadores de uso e modalidades de aplicação do orçamento de investimentos, ao passo que as outras são realizadas por ato da SOF. A LDO para 2011 (art. 66), por exemplo, autoriza que o decreto do Poder Executivo transponha dotações orçamentárias de 
uma unidade orçamentária para outra, no caso de reestruturação organizacional do Poder Executivo ou de transferência de atribuições de unidade, órgão ou entidade extintos, transformados, transferidos, incorporados ou desmembrados. Chama a atenção, ainda, que os recursos abertos por crédito extraordinário também podem, atualmente, ser remanejados por decreto, caso se destinem a outras despesas decorrentes de calamidades públicas (LDO 2011, art. 58, $\$ 2^{\circ}$ ).

Após a publicação desses atos no Diário Oficial da Uniāo, a SOF procederá à efetivação dos créditos publicados no SIDOR e transmitirá as informações à Secretaria do Tesouro Nacional (STN), que as disponibilizará no SIAFI e gerará as notas de dotação para as unidades gestoras que poderão utilizar os créditos adicionais.

\subsection{Iniciativa da fase legislativa}

A expressão processo legislativo refere-se ao "conjunto de atos (iniciativa, emenda, votação, sanção, veto) realizados pelos órgãos legislativos visando a formação das leis constitucionais, complementares e ordinárias, resoluções e decretos legislativos" ${ }^{217}$ A elaboração de leis financeiras (planos plurianuais, leis de diretrizes orçamentárias, leis orçamentárias anuais e créditos adicionais) segue procedimento legislativo especial, conforme enuncia o art. 166 da Constituição Federal.

O art. 42 da Lei n. 4.320/64 dispõe que "os créditos suplementares e especiais serão autorizados por lei e abertos por decreto executivo.” Faz parte das competências do Congresso Nacional analisar projetos de lei relativos a créditos adicionais, conforme o art. 166 da Constituição Federal. Cabe a uma comissão mista permanente de senadores e deputados "examinar e emitir parecer sobre os projetos referidos neste artigo [o que inclui aqueles sobre créditos adicionais] e sobre as contas anualmente apresentadas pelo Presidente da República" (art. 166, \$1º, I, CF).

A Constituição, porém, não define expressamente a competência para iniciar o processo legislativo de créditos suplementares e especiais. A questão da iniciativa legislativa em matéria financeira tem se mostrado mais complexa do que a tendência geral de imaginar o orçamento como atividade material do Executivo permitiria supor. Em vista da primazia do Poder Legislativo na atividade legiferante, a falta de previsão expressa de competência do Poder Executivo nessa matéria apenas pode conduzir à conclusão, bem expressa por Conti, de que a iniciativa legislativa nos projetos de lei de créditos suplementares e especiais não é reservada ao Chefe do Poder Executivo. Seguem a iniciativa geral do Poder Legislativo nos casos em que não há expressa disposição constitucional em contrário. ${ }^{218}$ Todavia, uma interpretação

217 SILVA, Curso de direito constitucional, cit., p. 524.

${ }^{218}$ CONTI, Iniciativa legislativa em matéria financeira, cit., p. 296. 
constitucional sistemática não deve permitir que o Poder Legislativo possa alterar dotações orçamentárias, na fase de execução, em casos nos quais não poderia fazê-lo na fase de elaboração. As limitações materiais às emendas parlamentares previstas no art. 166, $\$ 3^{\circ}$ da Constituição, se aplicam, portanto, também aos créditos suplementares e especiais, que devem ser compatíveis com o PPA e a LDO e indicar os recursos necessários, admissíveis àqueles provenientes da anulação de despesas. Evita-se, dessa maneira, que surjam iniciativas desarticuladas de créditos adicionais, comprometedoras do equilíbrio orçamentário e do planejamento.

\subsubsection{Período de vigência}

A vigência dos créditos adicionais fica adstrita ao exercício financeiro em que foram abertos, salva expressa disposição legal em contrário a respeito dos especiais e extraordinários (art. 45, Lei n. 4.320/64). A expressa disposição em contrário, todavia, ocorre no plano constitucional: de acordo com o art. 167, $\$ 2^{\circ}$ da Constituição, "os créditos especiais e extraordinários terão vigência no exercício financeiro em que forem autorizados, salvo se o ato de autorização for promulgado nos últimos quatro meses daquele exercício, caso em que, reabertos nos limites de seus saldos, serão incorporados ao Orçamento do exercício financeiro subsequente."

Vê-se, então, que a vigência dos créditos suplementares vai até o dia 31 de dezembro do respectivo exercício financeiro, independentemente da data em que tenham sido abertos; os créditos especiais e extraordinários poderão ter vigência superior à do exercício financeiro se o ato de sua autorização (lei, no caso dos especiais, e medida provisória, no caso dos extraordinários) for promulgado durante os últimos quatro meses do exercício. Serão, portanto, incorporados à execução orçamentária do exercício financeiro subsequente.

Essa vigência plurianual do crédito especial é justificada pelo fato do projeto de Lei Orçamentária Anual ser encaminhado ao congresso quatro meses antes do fim do exercício financeiro (art. 35, $\$ 2^{\circ}$, III, ADCT). Abrindo-se crédito especial nesse período, que vai de agosto e dezembro, fica claro que a despesa imprevista que se pretende criar não encontra dotação no orçamento subsequente, enviado ao congresso e em tramitação. Para garantir sua execução, portanto, admite-se sua reabertura.

\subsubsection{Transferências, remanejamentos e transposições}

As transferências de verbas entre dotações orçamentárias foram introduzidas no Brasil, a partir de inspiração legislativa francesa, para limitar o uso de créditos suplementares. Há alguma divergência, no entanto, quanto às origens. Castro Carreira 
datou a existência do estorno de verbas (isto é, a transferência entre dotações) em lei de 8 de outubro de 1843, do que discorda Agenor de Roure ao constatar que o orçamento para o exercício de 1833-1834 previa as transferências de recursos utilizando as sobras. ${ }^{219} \mathrm{Um}$ dos instrumentos para isso era, tanto em período monárquico como no início do republicano, a chamada Tabela B, bastante comum nos orçamentos, que previa uma lista com autorização prévia para abertura de créditos suplementares (antecessora das atuais "margens de remanejamento", das quais posteriormente se tratará). Caso também estas suplementações não fossem suficientes, o governo ficaria proibido de abrir créditos suplementares, ainda que pudesse, de início, recorrer ao estorno. A prática foi depois vedada. ${ }^{20}$

Quando o sistema orçamentário brasileiro admitia largamente despesas globais, o estorno podia ser livremente feito pelo governo, independentemente de previsão legislativa, porque o responsável pela execução da despesa dificilmente ultrapassava o limite de recursos que lhe havia sido traçado em linhas tão gerais. De fato, as dotações orçamentárias podiam ser vagas a ponto de possibilitar o atendimento das mais diferentes finalidades sob uma mesma rubrica.

O problema é antigo. O recurso ilimitado ao estorno desapareceu em 1878 (na França, os virements de crédit foram suprimidos em 1871), mas permaneceram os créditos suplementares depois de então. Acreditava-se, tanto no Brasil como na França, que a possibilidade de estornar verbas evitaria o uso de créditos adicionais e manteria o Executivo nos limites da dotação aprovada. Quando os virements de crédit se introduziram na legislação francesa, tinham semelhante finalidade de proibir o uso de créditos suplementares para cobrir despesas variáveis, mas a prática era diferente. $\mathrm{O}$ Brasil manteve-se crédulo por mais tempo a respeito dessa tese. $\mathrm{O}$ fracasso do estorno na França fez lá surgir o recurso aos orçamentos de retificação, criados por lei de 31 de Maio de 1862. Tratava-se de um segundo orçamento que modificava, de acordo com as necessidades, as previsóes e autorizações contidas na lei orçamentária anual. Nova tentativa de substituir o abuso aos créditos suplementares, ficando em recurso na França até o fim do império de Napoleão III. Adotava-se esse sistema de retificação também na Itália sob a denominação de "orçamento definitivo". ${ }^{221}$ Diversos foram os remédios, assim, para substituir os créditos suplementares. O uso do estorno sem autorização legal passou a ser no Brasil considerado crime contra a lei orçamentária, de acordo com o art. 10 da Lei n. 1.079,

\footnotetext{
219 ROURE, cit., p. 204.

220 ROURE, cit., p. 203.

221 ROURE, cit., p. 204.
} 
de 10 de abril de 1950, que tipifica os crimes de responsabilidade do Presidente da República.

A atual Constituição deixou de prever explicitamente, dentre as vedações orçamentárias, a proibição do estorno de verbas. Incluiu, entretanto, a vedação da transposição, do remanejamento e das transferências de uma categoria da programação para outra ou de um órgão para outro, sem prévia autorização legislativa (art. 167, VI). Em muitos sentidos não fica claro se esses instrumentos de flexibilidade têm natureza distinta dos créditos adicionais. Como a Constituição, porém, os tratou em item específico, separados das normas que regulam aqueles créditos, é necessário perquirir se há finalidades específicas, diferentes daquelas abrangidas pelos créditos adicionais, que devem ser por eles atendidas.

Para Machado Jr. e Teixeira Reis, algumas necessidades de alteração orçamentária não ensejam a abertura de créditos adicionais, mas a utilização de outros meios de flexibilização do orçamento. Reforma administrativa, repriorização das ações governamentais e repriorização de gastos produzem a necessidade de transposição, transferência ou remanejamento de recursos, respectivamente, e não provocam a alteração orçamentária por meio de créditos adicionais. Esses autores justificam sua posição argumentando que a ocorrência dos referidos fatos provoca alterações nos três níveis da programação orçamentária: institucional, programático e de gastos. No âmbito da organização (plano de programação institucional) há possibilidade de remanejamento de recursos. Assim, por exemplo, se ocorre reforma administrativa que extingue um órgão e cria outro em seu lugar, remanejam-se os recursos remanescentes daquele para esse. No plano programático podem ocorrer transposições, repriorizando-se programas de trabalho e deslocando-se recursos de programas entre si. Em termos de gastos, podem-se transferir recursos da categoria das despesas, no caso da prioridade dessa ser revista. São alterações orçamentárias, como se nota, que ocorrem por mudanças significativas no planejamento orçamentário. ${ }^{222}$ A diferença central entre os dois institutos estaria, portanto, no fato de que os créditos adicionais são abertos porque há necessidade de recursos até então inexistentes; no caso da transposição do remanejamento e da transferência está em realce a reprogramação por repriorização das ações.

É preciso esclarecer a que se refere a locução "categoria da programação" trazida pelo referido art. 167, VI, da Constituição. Trata-se, segundo a Portaria n. 42, de 14 de abril de 1999, do Ministério do Planejamento, Orçamento e Gestão, da função, da subfunção, do programa, do projeto/atividade/operação especial e das

${ }^{222}$ MACHADO Jr.; REIS, cit., p. 108. 
categorias econômicas de despesas. Vedando-se a transposição, o remanejamento ou a transferência de recursos de uma categoria da programação para outra ou de um órgão para o outro, realiza-se o princípio da vedação do estorno de verbas.

A diferença entre as três categorias estaria, portanto, na extensão da alteração que promovem: para alterações no nível institucional, remanejamentos; no nível da programação, transposições; no nível dos gastos, transferências. E essas formas jurídicas seriam diferentes dos créditos adicionais porque estes, ao contrário daquelas, não produzem alterações de maior relevância e impacto. Por isso é que deveriam ser utilizados com menos frequência e ser sempre precedidos de exposição justificativa. ${ }^{23}$

$\mathrm{O}$ argumento de que a diferença entre os créditos adicionais e as transferências aqui consideradas (para utilizar genericamente o termo, abrangendo também os remanejamentos e transposiçôes) está no fato de que apenas essas últimas alteram significativamente o planejamento parece extrair conclusões demais. Ainda que as suplementaçôes de verbas fossem fato de menor importância e impacto no orçamento, não fica claro em que a suplementação decorrente da anulação de outras dotaçōes orçamentárias se diferenciaria das transferências em sentido estrito aquelas que procedidas no plano dos gastos. A própria perspectiva de que alterar montantes orçamentários não é medida de maior relevância deve ser repensada: a especialidade do orçamento desdobra-se não apenas na definição dos programas, mas também em seus montantes, que são a medida da consecução dos programas.

Ademais, ao tentar distinguir estes institutos dos créditos adicionais, os critérios adotados se preocupam em fazer comparações com as suplementaçôes, isto é, com os créditos suplementares. Não abordam, entretanto, o aspecto dos créditos especiais, que fazem despesa nova. Não se trata aí, obviamente, de mero incremento na dotação (o que, repita-se, não é medida de impacto tão desprezível assim no planejamento), mas de criação de nova despesa. E isso não é decorrência necessária de emergências, calamidades, comoções etc., que ensejariam a abertura de créditos extraordinários, mas da própria repriorização de ações, de programas e de gastos, com atribuição de novos encargos a determinados órgãos incumbidos de realizar o novo gasto.

As margens de remanejamento orçamentárias, além disso, indicam frequentemente a possibilidade de usar recursos de outras dotações para cobrir as suplementações, que serão feitas por decreto do chefe do Executivo. ${ }^{224}$

223 Cf. Consulta n. 742.472/ TC-MG. rel. Min. Wanderley Ávila, 7/5/2008.

${ }^{224}$ Cf. as tabelas indicadoras dos recursos das portarias da SOF que regulam a abertura de créditos adicionais (Portarias n. 7, de 1 de março de 2011; n. 2, de 12 de janeiro de 2009; n. 7, de 
Por tudo isso, a diferença entre transposiçôes, remanejamentos e transferências e créditos adicionais não é evidente, e caberia à legislação complementar prevista no art. $165, \$ 9^{\circ}$, conferir densidade ao texto constitucional. $\mathrm{Na}$ forma atualmente prevista, em que a Lei n. 4.320/64 trata dos créditos adicionais, mas não dispõe das transferências, remanejamentos e transposições, não é possível identificar diferenças substanciais entre ambos os institutos. Os dois são utilizados para atingir o mesmo objetivo: cobrir despesas não previstas no orçamento, ou por meio da criação de novo programa, ou mediante o reforço da dotação anterior. Da mesma maneira, transferir, remanejar ou transpor recursos de uma dotação para outra necessariamente significará a diminuição de uma dotação para o aumento de outra: o incremento da dotação pode ser feito também por crédito adicional. Isso se reforça pelo argumento histórico, a introdução de modalidades de estorno de verbas no ordenamento jurídico brasileiro foi justificada com o fim de restringir o uso de créditos adicionais por meio da permissão de que despesas variáveis fossem atendidas pelas transferências ou pelo estorno. Atualmente, porém, essa restrição às despesas variáveis não encontra mais fundamento.

Da mesma forma, ambos os tipos de instrumentos de flexibilidade do orçamento seguem o processo legislativo similar. É preciso que haja autorização legislativa específica tanto para a abertura de créditos suplementares e especiais como para as transferências, remanejamentos e transposições.

Um comentário de lege ferenda merece ainda ser feito. Há muito se desviando da finalidade de atender exclusivamente despesas variáveis, encontram-se hoje procedimentos técnicos de estimativa e execução adequados ao seu bom atendimento, sem que sejam permitidas dotações globais ou créditos ilimitados. É, portanto, de se perguntar sobre a necessidade de permanência de institutos diversos dos créditos adicionais, visto que as necessidades de reprogramação mais profundas podem ser atendidas por esses sem prejuízo para a transparência das contas. Isso vem sido dito há algum tempo, e a conclusão não é nem nova nem original. Aproveitando-se de uma sugestiva ilustração, Agenor de Roure observava que, inseridos o sistema das transferências autorizadas por lei no sistema orçamentário para diminuir os créditos adicionais, ocorreu o mesmo que quando se colocou no país a formiga cuiabana para combater a saúva. Introduzida a primeira para combater a segunda, ficaram ambas. ${ }^{225}$

28 de março de 2008; n. 4, de 2 de fevereiro de 2007; n. 6, de 29 de maio de 2006; e n. 3, de 16 de março de 2005).

225 ROURE, cit., p. 204. 


\subsection{CONTROLE PARLAMENTAR FRACO}

\subsubsection{Créditos extraordinários}

Conquanto a Constituição vede a edição de medidas provisórias sobre matérias relativas a orçamento e a "créditos adicionais e suplementares" 226 (art. 62, $\$ 1$ 10, d), seu art. 167, $\$ 3^{\circ}$ aponta ser aquela espécie normativa a adequada para a abertura de créditos extraordinários, que são aqueles destinados a despesas imprevisíveis e urgentes. O uso de medida provisória em matéria orçamentária exige, pois, além dos característicos de urgência e relevância dessa espécie, o requisito da imprevisibilidade que justifica a ação excepcional por crédito extraordinário. Nesse sentido, a norma constitucional de 1988 revogou o art. 44 da Lei n. 4.320/64, que previa o decreto do Poder Executivo para sua abertura. A edição de ato administrativo próprio do chefe do Poder Executivo fazia parte da tradição orçamentária brasileira referente à matéria. A nova norma parece vir em um contexto de valorização do Poder Legislativo no processo orçamentário, pelo que esse deve se manifestar, ainda que posteriormente, mas de maneira definitiva, sobre norma introdutora de créditos extraordinários.

Embora a referência à submissão dos créditos extraordinários à forma e ao procedimento de medida provisória seja, no art. $167, \$ 3^{\circ}$ da Constituição, feita em redação confusa, ${ }^{227}$ sem referência direta a esta espécie normativa, não há como prosperar a posição de que a interpretação que vem sendo feita do dispositivo é equivocada. ${ }^{228} \mathrm{O}$ art. $62, \S 1^{\mathrm{o}}, d$, ao vedar medida provisória em matéria de créditos adicionais, ressalva explicitamente o disposto no art. $167, \S 3^{\circ}$, que se refere aos créditos extraordinários. Não bastasse, seria necessário indicar que outra espécie normativa ou ato administrativo seriam adequados para abrir esse tipo de crédito, no caso de ser inapta a medida provisória. O retorno ao sistema dos decretos não encontra mais respaldo no texto constitucional - contraria o esquema de prerrogativas parlamentares na aprovação de mudanças no orçamento público. Em nenhum momento a Constituição autoriza o decreto em matéria orçamentária, que

${ }^{226}$ Note-se a imprecisão terminológica do legislador constituinte neste dispositivo, como se os créditos suplementares não fossem espécies de créditos adicionais.

${ }^{227}$ Art. 167, $\$ 3^{\circ}$ : A abertura de crédito extraordinário somente será admitida para atender a despesas imprevisíveis e urgentes, como as decorrentes de guerra, comoção interna ou calamidade pública, observado o disposto no art. 62. (Grifo nosso).

${ }^{228}$ Para negar a possibilidade de abertura por medida provisória, cf. SANCHES, O. M., Processo orçamentário federal: problemas, causas e indicativos de solução. Revista de Administração Pública, Rio de Janeiro, v. 29, n. 3, p. 146-7, jul.-set. 1995. 
se assemelharia a um decreto autônomo por inovar a lei. É indispensável, portanto, a autorização legislativa, ainda que, neste caso, se dê apenas em momento posterior. Por tudo isso, a medida provisória é medida cabível.

A necessidade de fazer com que necessidades públicas urgentes possam ser dispensadas da aprovação por lei, mais demorada, para seu pronto atendimento, existe também em outros sistemas constitucionais. A Constituição alemã foi mais detalhada em seu art. 112 ao admitir a adoção de despesas que ultrapassem ou estejam fora do orçamento, com o requisito de que se trate de uma necessidade imprevista (unvorhergesehen) e inevitável (unabweisbar). O Tribunal Constitucional Federal, em decisão de 25 de maio de 1977, ${ }^{229}$ determinou que a imprevisibilidade não pode ser exclusivamente interpretada em seu sentido objetivo. Assim, imprevista não é apenas a necessidade objetivamente imprevisível, mas também aquela que, de fato e independentemente do motivo, não foi prevista pelo governo ou pelo parlamento na aprovação do orçamento. Ou então aquela despesa cuja crescente urgência, que entrementes se originou de mudanças nas circunstâncias, tampouco foi prevista. ${ }^{230}$ Ainda que por erro do planejamento do governo, ou desatenção do legislativo, ou menosprezo do risco de mudanças conjunturais, é admitida a adoção destas alteraçôes orçamentárias (über-und au erplanmä ige Ausgabe, art. 112, GG). Combinadas, porém, com o outro requisito: o da inevitabilidade.

$\mathrm{Na}$ mesma decisão da corte constitucional alemã, definiu-se o requisito da inevitabilidade em função da urgência da despesa, tanto em termos materiais (a relevância da matéria) como temporais (sua impostergabilidade). Somente se qualifica como inevitável o gasto que não possa ser deixado para frente sem prejuízo de sérios interesses políticos, econômicos e sociais do Estado. Essa barreira à competência do ministro das finanças significa que apenas abre-se espaço para a observação da inevitabilidade se a despesa adicional for tão urgente que não possa aguardar um orçamento adicional ou um orçamento complementar ou simplesmente sua inclusão no orçamento do próprio exercício financeiro subsequente. ${ }^{231}$ Com base

229 BVerGE 45, 1 (1977).

${ }^{230}$ No original: "Unvorhergesehen ist nicht nur ein objektiv unvorhersehbares Bedürfnis, sondern jedes Bedürfnis, das tatsächlich, gleich aus welchen Gründen, vom Bundesminister der Finanzen oder der Bundesregierung bei der Aufstellung des Haushaltsplans oder vom Gesetzgeber bei dessen Beratung und Feststellung nicht vorhergesehen wurde oder dessen gesteigerte Dringlichkeit, die es durch Veränderung der Sachlage inzwischen gewonnen hat, nicht vorhergesehen worden ist." (BVerGE 45,1[98]).

231 No original: "Nur wenn eine Ausgabe ohne Beeinträchtigung schwerwiegender politischer, wirtschaftlicher oder sozialer Staatsinteressen nicht mehr zeitlich aufgeschoben werden kann, besteht für sie ein unabweisbares Bedürfnis. Diese Schranke für die Kompetenz des Bundes- 
nesse entendimento, o Tribunal Constitucional Federal alemão não tem se furtado a declarar nulas essas despesas não contidas no orçamento e mesmo orçamentos adicionais inteiros (Nachtragshaushaltsgesetze), nos quais as incompletudes e insuficiências nas estimativas iniciais tornem inaplicáveis os princípios constitucionais da transparência, da exatidão e da sinceridade orçamentárias, destinando-se os orçamentos do meio de exercício a promover o endividamento público em limites significativamente maiores que aqueles informados no orçamento inicial. ${ }^{232}$

Ambas as definições reforçam que os instrumentos de flexibilidade orçamentária não estão à disposição do chefe do Executivo para mudar o orçamento quando e como ele quiser; está autorizado a alterá-lo em razão de necessidades circunstanciais imprevistas, urgentes e impostergáveis.

Inobstante a participação do Poder Legislativo, ela se dá em momento posterior, seguindo os prazos para aprovação de medida provisória, quando uma ocasional rejeição pode ser inócua: a despesa pode ter sido realizada, criando-se um fato consumado. Isso é agravado pela falta de clareza quanto às hipóteses em que é cabível a abertura do crédito extraordinário.

A disciplina constitucional dos créditos extraordinários, que o direito brasileiro não tratou a questão das alterações orçamentárias da mesma maneira como é feito na Alemanha, cuja Constituição Financeira serviu de modelo à organização das leis orçamentárias brasileiras. A diferença está na interpretação do que significa a imprevisibilidade. No direito alemão, como visto, a norma constitucional não se cinge à imprevisibilidade objetiva, podendo ser cobertas por créditos extraordinários mesmo aquelas despesas que podiam ser perfeitamente previstas, mas não o foram, independentemente do motivo. A Constituição brasileira, porém, fornece elementos para que se entenda a imprevisibilidade em termos mais objetivos, embora não o diga expressamente. Isso porque o art. $167, \$ 3^{\circ}$ exemplifica situações que serão atendidas por essa medida orçamentária emergencial, fala em situações "como as decorrentes de guerra, comoção interna ou calamidade pública”. A Carta indica sua preferência por situações graves, marcadas pela imperiosidade de seu atendimento. A urgência e imprevisibilidade se tornam requisitos mutuamente dependentes para caracterizar a legitimidade constitucional da abertura de créditos extraordinários,

ministers der Finanzen bedeutet: Erst wenn eine Mehrausgabe so eilbedürftig ist, dass die Einbringung eines Nachtragshaushaltsplans oder eines Ergänzungshaushaltsplans oder schließlich ihre Verschiebung bis zum nächsten regelmäßigen Haushalt bei vernünftiger Beurteilung der jeweiligen Lage als nicht mehr vertretbar anerkannt werden kann, liegt ein Fall der Unabweisbarkeit vor.” (BVerGE 45,1[102])

232 BVerfG, 2 BvF 1/2004, de 9/7/2007, parágrafos 1-220. 
não podendo ser atendidos por esse instrumento aqueles casos em que a despesa não prevista está despida da nota da emergência. Os exemplos constitucionais não permitem que se equipare o erro de planejamento do governo, que não previu despesas corriqueiras, a casos de relevante magnitude e comoção social. Por isso, a imprevisibilidade não é uma medida em si, mas é qualificada pela urgência.

$\mathrm{O}$ abuso no uso dos créditos extraordinários tem suscitado o interesse da jurisprudência constitucional, chamada a se pronunciar sobre a inconstitucionalidade dessas medidas provisórias. O controle de constitucionalidade dos requisitos dos créditos extraordinários não encontrou, senão recentemente, guarida no Supremo Tribunal Federal. Uma série de decisões negava a possibilidade desse controle, escorando-se em argumentos que reforçavam a execução orçamentária como competência exclusiva do Poder Executivo. Repetia-se que:

Os atos orçamentários têm a natureza meramente de lei formal, de efeitos concretos e limitados, portadores de normas individuais (ADI 1.716/DF, rel. Min. Sepúlveda Pertence).

O requisito da previsibilidade não decorre objetivamente do ato atacado, isto é, do crédito extraordinário aberto por medida provisória, mas de outra lei - a lei orçamentária anual, cujo exame seria indispensável, mas impossível (ADI 1.496/DF, rel. Min. Moreira Alves);

A jurisprudência da corte estava suficientemente consolidada no sentido das leis orçamentárias serem atos administrativos revestidos simplesmente da forma de lei (ADI 2.925/DF, rel. Min. Ellen Gracie).

$\mathrm{O}$ art. $21, \$ 1^{\mathrm{o}}$, do Regimento Interno do Supremo Tribunal Federal diz ser impróprio o controle abstrato de constitucionalidade sobre matéria desprovida de generalidade, abstração e impessoalidade (ADI 3.487/DF, rel. Min. Ellen Gracie).

Não caberia ao STF, por obediência ao princípio da separação de poderes, aferir a substância mesma da despesa, o que é indispensável para verificar sua imprevisibilidade (ADI 3.709/DF, rel. Min. Celso Peluzo; ADI 3.712/DF, idem).

A Corte experimentou recentemente uma alteração nesses paradigmas de controle de constitucionalidade de medidas provisórias e de matéria orçamentária. De início, na ADI 3.891/DF, cujo relator foi o ministro Ricardo Lewandowski, caminhava-se à aplicação da jurisprudência da Casa, em um caso em que a Medida Provisória n. 364, de 18 de abril de 2007, abriu crédito extraordinário em favor de diversos ministérios (Educação, Justiça, Transportes, Esportes, Integração Nacional e Cidades) no valor de $\mathrm{R} \$$ 1.717.041.026,00, destinado ao apoio ao desenvolvimento da educação básica, complementação ao Fundef, obras de infraestrutura 
para os Jogos Pan-americanos de 2007, conservação de rodovias federais, construção da Ferrovia Norte-Sul, entre outros. Mais se assemelhava a um orçamento retificativo que a um crédito extraordinário, em razão da diversidade de seus objetivos. O Partido Popular Socialista (PPS), autor da ação, alegou inexistência do binômio urgência-imprevisibilidade, denunciando a falta de planejamento. Segundo o Ministro Gilmar Mendes, a reiteração de decisões pretéritas do STF estava colocando a salvo do controle de constitucionalidade um sem-número de leis, o que provocava enorme insegurança jurídica. Afirmou, ainda, que não se discute a impossibilidade de que atos sem caráter de generalidade se submetam ao controle abstrato das normas, mas situação diversa é a de atos editados sob a forma de lei. A Constituição não fez distinção entre leis conformadas com ou sem o atributo da generalidade e da abstração. Assim, se o constituinte preferiu que determinados atos, ainda que de efeitos concretos, fossem submetidos à forma de lei, não cabe ao intérprete debilitar a garantia constitucional e isentar inúmeras leis do controle de constitucionalidade. Confirmou entendimento exposto pela doutrina constitucional, e que se lê em Manoel Gonçalves Ferreira Filho, 233

[a] lei ordinária é um ato legislativo típico. É um ato normativo primário. Em regra, edita normas gerais e abstratas, motivo por que, na lição usual, é conceituada em função da generalidade e da abstração. Não raro, porém, edita normas particulares, caso em que a doutrina tradicional a designa por lei formal, para sublinhar que lei propriamente dita só é aquela, a que tem matéria de lei, por isso chamada de "lei material”. Essa distinção, contudo, não traz vantagens, além de não ser, muita vez, fácil de marcar. De fato, quanto ao momento de sua instauração e, sobretudo, quanto à eficácia (que é o mais importante), a lei dita material e a lei dita formal estão num só e mesmo plano.

Não se pode deixar de dizer que o encaminhamento dessa questão encontrava eco na ADI 2.925, anteriormente citada, em que não se acompanhou o voto da relatora, ministra Ellen Gracie. Aí, embora se afirmasse a impossibilidade do controle concentrado em normas de efeitos concretos, permitiu-se o controle da parte da Lei de Diretrizes Orçamentárias que contivesse dispositivo genérico. Com esse caráter entendeu-se a regulação prevista na LDO dos limites para abertura de créditos suplementares previamente autorizados pela LOA, especificamente quanto ao remanejamento de recursos da CIDE-Combustíveis. Haveria, então, um desvio das finalidades traçadas pelo art. $177, \$ 4^{\circ}$ da Constituição para essa espécie tributária. No limite, a indenidade das margens de remanejamento ao controle de constitucionalidade permitiria o afastamento das vinculações constitucionais de recursos públicos, livremente transitáveis dentro do orçamento.

233 FERREIRA FILHO, M. G. Do processo legislativo. 5. ed. São Paulo: Saraiva, 2002, p. 204. 
Decisão paradigmática, ainda, foi proferida na ADI 4.048/DF, de relatoria do Ministro Gilmar Mendes, proposta pelo Partido da Social Democracia Brasileira (PSDB), contra a Medida Provisória n. 405/2007, que abriu crédito extraordinário em favor da Justiça Eleitoral e de diversos órgãos do Poder Executivo, no valor global de $\mathrm{R} \$$ 5.455.677.660,00. Embora não seja um elemento juridicamente relevante para tornar admissível o controle de constitucionalidade, o crédito impressionava pelo volume, contribuindo para que aquele exercício de 2007 alcançasse o maior montante de recursos abertos por créditos extraordinários em uma série de dez anos (cf. Gráfico 1). Afirma o relator que o requisito da imprevisibilidade não se submete apenas ao juízo político, mas apresenta, na Constituição, feição de maior objetividade que os elementos de relevância e urgência, reconhecendo a tese da característica objetiva da imprevisibilidade. Da análise da exposição de motivos da Medida Provisória 405/2007, porém, não se depreende serem as despesas que se pretendem atender imprevisíveis e urgentes. Ainda que se reconheça a intenção de evitar situações de crise decorrentes dos problemas apontados, não se pode dizer que essas circunstâncias eram inesperadas. Ademais, em muitos dos casos, trata-se de requerer despesas para prevenir situações, o que indica, por si só, sua previsibilidade. Outro aspecto relevante, segundo o relator, ${ }^{234}$ é que "[i]mpressiona a quantidade elevada de medidas provisórias editadas, no último ano, pelo Presidente da República, para abertura de créditos suplementares ou especiais travestidos de créditos extraordinários. Desde o início do ano de 2007, se podem contar mais de vinte medidas provisórias destinadas à abertura de créditos de duvidosa natureza extraordinária."

A análise dessas ações levadas ao STF e a nova orientação imprimida a tais casos pela Corte têm demonstrado que os requisitos constitucionais para a abertura de créditos extraordinários não são cumpridos e que a discriminação estabelecida entre créditos suplementares, especiais e extraordinários não tem assumido grande significação na prática, tomando-se um pelo outro de acordo com a conveniência e a ocasião. Não menos importante é que tais decisões mostraram que esses vícios podem ser arguidos em controle concentrado de constitucionalidade.

Outro aspecto a ser analisado a respeito dos créditos extraordinários é que, sendo eles próprios instrumentos de flexibilidade, são também passíveis de flexibilização pelo contingenciamento de recursos. Isso demonstra uma incongruência entre os diversos instrumentos de flexibilidade orçamentária: Se o crédito extraordinário foi aberto para atender a uma despesa urgente, que sentido faz suspender sua execução? Nota-se que em alguns exercícios financeiros há uma cunha entre os créditos extraordinários previstos e sua quantia executada, notadamente a partir de 2004.

${ }^{234}$ ADI - MC/DF, rel. Min. Gilmar Mendes, de 15de maio de 2008, p. 88. 
Percebe-se que o índice mais baixo de execução em determinados intervalos de tempo (de 2004 a 2008) traz ao menos duas delicadas questôes. De um lado, é altamente questionável a obediência ao requisito da urgência para os créditos extraordinários, visto que os montantes previstos não foram gastos. De outro, podem-se supor deficiências do atual sistema de planejamento orçamentário, pois, sendo apenas em pequena parte executada, é duvidoso que a despesa fosse tão relevante que não pudesse esperar sua inclusão no orçamento do próximo ano. Esses dados quantitativos podem apontar para o descumprimento do requisito constitucional da imprevisibilidade - e o insuficiente controle que vem sendo exercido pelo Poder Legislativo a esse respeito.

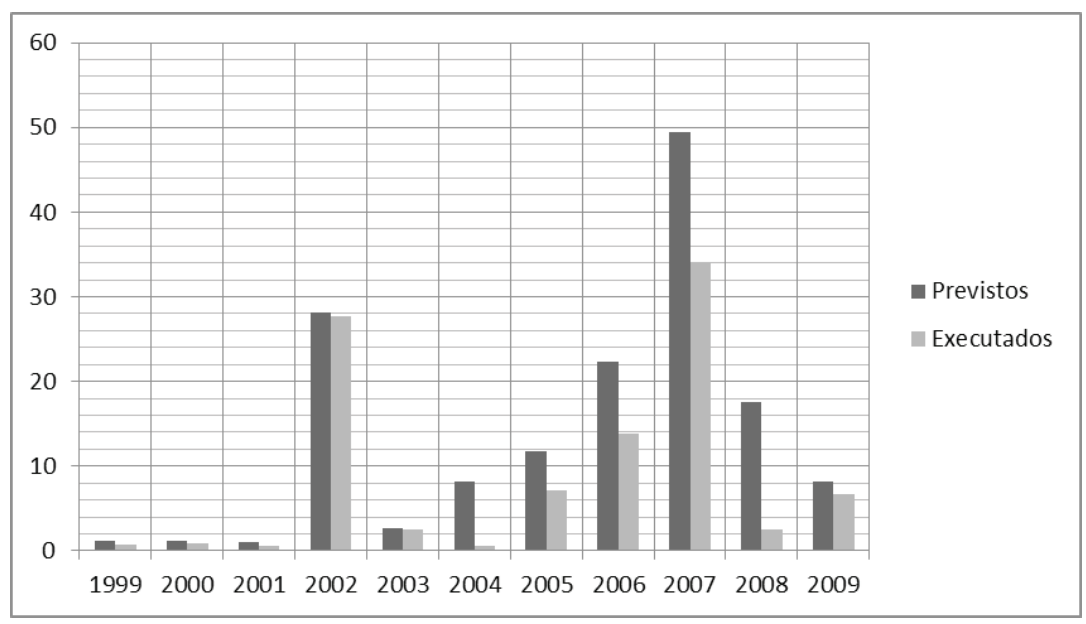

Figura 3.1 Créditos Extraordinários Autorizados e Executados de 1999 a 2009.

\subsubsection{Créditos suplementares autorizados na LOA}

O parlamento tem fracas condições de participar da abertura de créditos extraordinários, pois sua participação ocorre em momento posterior, no qual o gasto pode até mesmo se ter efetuado. Torna-se prejudicial, portanto, a previsão de que esse controle não seja prévio. Em outros casos de créditos adicionais, porém, o problema está em que a atuação do Poder Legislativo, além de não ser prévia, sequer é específica. Trata-se dos créditos suplementares cuja abertura é autorizada previamente na lei orçamentária anual, por decreto do Poder Executivo.

O comando do art. 165, $\$ 8^{\circ}$ da Constituição repetiu, sem alteração do texto, preceito que ininterruptamente tem feito parte das constituições brasileiras desde a Reforma Constitucional de 1926, que acrescentou $₫ 1^{\circ}$ ao art. 34 da Constituição 
de 1891. Essa reforma destinava-se a eliminar as chamadas caudas orçamentárias, afirmando o princípio da exclusividade de modo a evitar que dispositivos sem conteúdo orçamentário fossem incluídos na lei de orçamento. Disso se extrai a existência de um conceito constitucional de matéria orçamentária (isto é, matéria própria da lei de orçamento), que, no seu sentido constitucional, apenas pode ser a previsão de receitas e a fixação de despesa. A vedação, entretanto, não é absoluta e o texto constitucional previu duas exceçóes: além da matéria orçamentária propriamente dita, a lei orçamentária poderá conter autorização prévia para a abertura de créditos suplementares, comumente denominada de margem de remanejamento, e a autorização para contratação de operações de crédito. São duas exceções que, como visto, não inovam a tradição orçamentária brasileira: a previsão da autorização para abertura de créditos suplementares reaviva a velha Tabela B dos primeiros orçamentos brasileiros. Embora as atuais margens de remanejamento não contenham exatamente uma lista específica de serviços cujas dotações são suplementáveis, elas trazem hipóteses bastante detalhadas de sua utilização, apontando suas fontes de recursos e os limites percentuais remanejáveis de diferentes dotações. Pode-se dizer, assim, que a atual Seção III da lei de orçamento substitui a tão atacada e debatida Tabela B, com algumas diferenças.

A reforma de 1926 tinha um propósito, porém, específico: que os créditos suplementares previamente autorizados se destinassem apenas às despesas variáveis, que não puderam ser exatamente quantificadas. Sua finalidade seria somente autorizar que serviços passíveis de estimação aproximativa não necessitassem de autorizações legislativas para cada caso, e o governo poderia atender às diferenças transferindo recursos dentro do próprio orçamento. Pontes de Miranda, ao comentar dispositivo idêntico da Constituição de 1934, manifestou-se favoravelmente a tais margens por esta razão: eram medidas afins "às verbas orçamentárias e à economia dos orçamentos". Ressalvou, entretanto, que " $[\mathrm{t}]$ udo aconselha que, no caso dos créditos suplementares, se determinem de antemão os serviços para os quais podem ser abertos e a quanto podem montar de per si e em quais condições", ${ }^{235}$ reforçando a necessidade de alguma tipificação para evitar abusos da parte do Poder Executivo.

A prática tem se sofisticado nas sucessivas leis orçamentárias federais e se tornado um poderoso instrumento para alterar a lei orçamentária. É também na prática que se tem colocado tal instrumento à disposição do governo. Essa sofisticação decorre do detalhamento cada vez maior das hipóteses em que a administração pública federal pode utilizar-se dos recursos previstos para a abertura de créditos

235 PONTES DE MIRANDA. Comentários à Constituição da República dos Estados Unidos do Brasil. Rio de Janeiro: Guanabara, 1936, p. 547-548, t. I. 
suplementares para atender às hipóteses previstas para essa modalidade, que seriam aquelas provenientes da necessidade de reforço da dotação prevista.

A importância de tais margens de remanejamento para a gestão orçamentária pode ser indicada pela atenção cada vez maior que as leis orçamentárias dão ao assunto, criando cada vez mais hipóteses de sua aplicação e reforçando a plena institucionalização do procedimento na prática política orçamentária. Habitualmente fixada em $10 \%$ do valor de cada subtítulo, o orçamento de 2011 foi pródigo em expandir a abrangência da autorização, que passou a ser de $25 \%$ para investimentos (art. $4^{\circ}$, II, da Lei n. 12.381, de 9 de fevereiro de 2011), o que é abertamente medida destinada a conferir maior maleabilidade à gestão do Plano de Aceleração do Crescimento (PAC). O percentual proposto pelo governo era ainda maior, de 30\%, mas as negociaçôes para aprovação deste orçamento o reduziram. ${ }^{236}$ Pelo caput do art. $4^{\circ}$ da lei orçamentária para 2011, não é difícil antever um dos itens desta pauta de negociação entre parlamentares e governo, pois ficaram expressamente excluídos da margem de remanejamento os recursos destinados ao atendimento de emendas parlamentares individuais e coletivas.

Essa situação denota as deficiências do sistema de planejamento, incluindo-se espaços de livre disposição no orçamento, os quais chegam a um quarto das verbas de investimentos no caso federal. De outra parte, demonstra também que a atuação política parlamentar tende a ignorar as questôes públicas gerais de planejamento e políticas públicas, atendo-se à aprovação de emendas que lhe tragam as vantagens político-eleitorais que a discussão abstrata sobre programas de governo e condiçōes macroestruturais do país dificilmente traria.

A situação pareceria mais grave não houvesse países nos quais a execução orçamentária tem sido inegavelmente entregue apenas ao Executivo em uma intensidade ainda mais forte que a brasileira. Na Argentina, a margem de remanejamento orçamentária constitui instrumento tão usual que, para sua utilização, não é sequer necessário decreto presidencial. Nesse país, tem-se operado um processo de delegação das competências orçamentárias do próprio chefe do Executivo para outros órgãos administrativos e é suficiente ato do chefe do gabinete de ministros para modificar dotações orçamentárias. ${ }^{237}$

236 Informações divulgadas pelo órgão oficial de comunicação do Senado Federal dão conta de que o acordo partidário que permitiu a aprovação do referido orçamento teve como um dos pontos de negociação a redução desta margem de remanejamento (Orçamento assegura ao governo flexibilidade para usar verba do PAC. Jornal do Senado, Brasília, 23 de dezembro de 2010, p. 3).

237 ARGENTINA. Ministerio de Economía y Finanzas Públicas. El Sistema Presupuestario en la Administración Nacional de la República Argentina. Buenos Aires: Gobierno Federal, 2008, p. 150. 
Chama a atenção, também, que a competência para autorizar genérica e anteriormente a abertura de créditos suplementares é do Poder Legislativo, mas os termos desta autorização vêm colocados pelo Executivo - que tem determinado o modo de exercício da competência privativa de outro Poder. Embora o mesmo ocorra quanto às leis orçamentárias, não se pode esquecer que a margem de remanejamento é um acréscimo ao orçamento, uma "cauda", e não se trata propriamente de matéria orçamentária, pois não contém previsão de receita nem fixa despesa. É, antes, uma autorização para modificar o orçamento, que adere à LOA como um rabilongo, um rider, bepackung ou cavalier budgetaire, tais como denominados em outros sistemas.

A posição proeminente do Poder Legislativo no quadro da separação de funções orçamentárias, contudo, leva a questionar, novamente, a forma como lhe cabe participar da execução orçamentária na hipótese aqui considerada. Pois compondo apenas formalmente a lei orçamentária, visto que não prevê receitas nem fixa despesas, trata-se tão somente de um acréscimo cuja inclusão naquela lei a Constituição autorizou, por razões de celeridade e de uma certa aproximação de conteúdo. Se pode estar ali incluída (e claro está a tratar de uma permissão e não de um dever), nada impede que não esteja. E no caso de se optar por veicular tais margens de remanejamento por outra espécie normativa que não a lei orçamentária, cabe indagar qual seria ela.

Sinteticamente, trata-se de uma autorização prevista em lei para que essa mesma lei possa ser alterada por decreto. Ocorre uma autorização genérica do Poder Legislativo ao Executivo para que esse regule situações orçamentárias específicas de utilização de recursos para fins diversos daqueles aprovados, por ato próprio. Não é possível, porém, dizer que se trata de um caso de delegação constitucionalmente autorizada (por norma constitucional originária) de competência legislativa, como propôs o ministro Nelson Jobim na discussão da ADI 2925-8/DF.238 A única hipótese expressamente prevista para delegação de competência legislativa é a das leis delegadas, de raro uso na prática constitucional brasileira. Da mesma forma, seu procedimento é significativamente diverso daquele previsto para as margens de remanejamento. Conforme estatui o art. 68 da Constituição, a delegação é solicitada pelo Presidente da República ao Congresso, que a outorga por meio de resolução que especifica seu conteúdo e os termos de seu exercício. Os créditos suplementares previstos na margem de remanejamento são abertos, por sua vez, não por lei

238 Cf. STF. ADI 2925-8/DF. Relatora Ministra Ellen Gracie. Julgamento em: 11.12.2003, publicado no DJ em 4 de março de 2005, p. 157. Disponível em: <http://redir.stf.jus.br/paginadorpub/paginador.jsp?docTP=AC\&docID=266953>. Acesso em 12 fev. 2012. 
delegada, mas por decreto do presidente da República. É patente a inadequação de enquadrar as autorizações prévias de abertura de créditos suplementares como hipótese de delegação legislativa, prevista pelas normas constitucionais que regulam o processo legislativo federal.

Cabe, em primeiro lugar, indagar da competência para autorizar previamente a abertura de créditos suplementares. Esta só pode ser do Poder Legislativo, do contrário sequer necessitariam ser previstas na lei de orçamento: bastaria ato do chefe do Poder Executivo. Seria, neste sentido, um contrassenso que o presidente da República, no caso federal, necessitasse autorizar a si próprio. Logicamente, portanto, trata-se de competência parlamentar. Mais do que isso, tem-se que tal autorização constitui competência exclusiva do Poder Legislativo, que não a poderia delegar a outro Poder sob pena de renunciar a suas prerrogativas constitucionais. Sua veiculação pode dar-se, portanto, por meio de decreto legislativo, pois é essa a espécie normativa destinada a veicular matéria de competência exclusivamente parlamentar. Embora os temas a ele sujeitos estejam basicamente previstos no art. 49 da Constituição, esse rol não é exaustivo.

A lei orçamentária frequentemente contém, assim, matéria de decreto legislativo unida a outros preceitos orçamentários, aderente à lei e a seu procedimento específico, como verdadeira "cauda orçamentária". Isso implica que eventual veto aposto pelo chefe do Executivo ao orçamento não se estende, de forma automática, à margem de remanejamento, pois não há participação do Executivo na edição de decretos legislativos. Esses se incluem no orçamento não como dispositivo orçamentário, mas como acessório àquela lei, por uma exclusiva questão de celeridade. É o que percebeu Aureliano Leal, um dos poucos constitucionalistas a se dedicar mais profundamente ao tema a respeito de dispositivo idêntico da Constituição de 1891, a ela adicionado em 1926. Ao discorrer sobre a natureza jurídica da lei de orçamento, observou que ela continha diversos dispositivos de conteúdo material (entenda-se, com sentido de lei material), dentre os quais este de conteúdo não orçamentário: a autorização prévia para a abertura de créditos suplementares. E, por se tratar de competência exclusiva do congresso autorizá-la, "a autorização para abrir créditos suplementares também não pode deixar de ser considerada um decreto legislativo."239

Uma consequência importante dessa ideia para as negociações entre o governo e parlamento, além de reforçar a extensão das competências parlamentares na fase de execução orçamentária, é que as dificuldades para atingir um acordo sobre os

239 LEAL, A. Theoria e prática da constituição federal brasileira. Rio de Janeiro: F. Briguiet e Cia. Editores, 1925, p. 501. 
limites da margem de remanejamento não devem, necessariamente, impedir a aprovação da lei orçamentária em si, permitindo evitar o prejuízo de uma lei orçamentária tardia. A solução é destacar a seção de seu texto referente a tais autorizações, que podem ser concedidas posteriormente por decreto legislativo, pois essa é seu veículo próprio.

O problema da qualificação jurídica da margem de remanejamento não esgota, porém, a discussão sobre a necessidade de sua permanência no sistema constitucional orçamentário. Hipótese rara de encontrar no direito orçamentário estrangeiro, a autorização prévia para ampla suplementação de receitas é exceção ao princípio da especificação (à medida em que se autoriza a transferência de recursos entre programas sem autorização legislativa específica) que compromete o controle parlamentar e confere poucos incentivos ao planejamento da ação governamental. Isso é feito sem que muitas vezes se dê conta de outras possibilidades interpretativas presentes no texto constitucional, decorrentes de uma sistemática apreciação das possibilidades de participação parlamentar na execução do orçamento.

\subsection{CONTROLE PARLAMENTAR FRAQUÍSSIMO: LIMITAÇÃO DE EMPENHO E MOVIMENTAÇÃO FINANCEIRA}

A Lei de Responsabilidade Fiscal (Lei Complementar n. 101/2000) atribuiu novas funções à Lei de Diretrizes Orçamentárias, dentre as quais a necessidade de que ela confira parâmetros à programação financeira e ao cronograma de execução mensal de desembolso. Isso é previsto em seu art. $8^{\circ}$.

Essa programação é instrumento de planejamento, como já visto, por meio da qual se ajusta o ritmo de execução orçamentária ao fluxo de recursos financeiros disponíveis. Compete-lhe permitir a liberação de recursos aos programas orçamentários. Para tanto, o cronograma opera de acordo com as metas do Anexo de Metas Fiscais, outra inovação trazida pela Lei de Responsabilidade Fiscal e incorporada à Lei de Diretrizes Orçamentárias (art. 9º). A medida tem o objetivo claro de vincular a administração ao maior controle sobre os gastos públicos, indicando tanto o equilíbrio orçamentário como a transparência dos compromissos governamentais com a dívida pública. ${ }^{240}$

O monitoramento do cumprimento das metas fiscais primárias e nominais previstas no Anexo de Metas Fiscais é feito de forma contínua, durante todo o processo de execução orçamentária. O cálculo das Necessidades de Financiamento

${ }^{240}$ BRASIL. Ministério do Planejamento. Manual técnico orçamentário para 2011, cit., p. 83. 
do Governo Central (NFGC) serve como referência para evidenciar a trajetória das receitas e das despesas. Os fatos supervenientes que impliquem alteração nas alocações orçamentárias têm repercussão sobre todo o processo de execução, tornando necessária a revisão dos limites orçamentários e da programação financeira.

Diante de limitaçôes ao poder de gastar, o governo deixa de executar parte do orçamento, promovendo o chamado contingenciamento das despesas empenhadas. Cabe ao chefe de cada Poder publicar ato que contenha o montante indisponível, estabelecendo quanto seus órgãos terão como limite de movimentação financeira e empenho, nos termos do art. $9^{\circ}$. O Poder Executivo também comunicará esses limites aos Poderes Legislativo e Judiciário e ao Ministério Público. O $\$ 3^{\circ}$ do citado artigo estatui que, no caso destas três esferas não promoverem a limitação no prazo estabelecido, o Poder Executivo fica autorizado a limitar os valores financeiros segundo os critérios fixados pela LDO.

Como a finalidade da limitação de empenho é ajustar o ritmo de execução da despesa à arrecadação, assim que for restabelecida a receita prevista, mesmo que de maneira parcial, as dotações contingenciadas devem ser recompostas proporcionalmente àquilo que foi reduzido em face dos critérios estabelecidos pela LDO.

Algumas despesas, porém, não se submetem a essas regras. São aquelas que configuram obrigações legais e constitucionais de responsabilidade dos entes federativos, assim como aquelas destinadas ao pagamento do serviço da dívida pública e outras expressamente ressalvadas na lei de diretrizes, conforme a opção do legislador.

Nota-se que esse quadro normativo prevê a limitação de empenho como recurso para não comprometer a política fiscal e garantir a formação de superávit primário ou nominal, cumprindo os objetivos do Anexo de Metas Fiscais. O diferimento do pagamento da despesa, porém, está longe de cumprir apenas estes objetivos.

Essa disciplina normativa poderia vir a indicar que a Lei de Responsabilidade Fiscal expandiu as possibilidades de que o Executivo contingencia recursos - tanto mais que estabeleceu até mesmo a possibilidade de limitação de empenho realizado por outros poderes. As possibilidades ainda são amplas, mas algo parece indicar que a referida lei, ao tratar do assunto, acabou por reprimir, e não por expandir, as possibilidades de que o Poder Executivo lance mão deste recurso.

Antes da previsão normativa, a decisão governamental de não gastar se fundamentava, evidentemente, no caráter autorizador da lei de orçamento. Como o orçamento estabelece tetos, e executar a despesa é uma decisão administrativa tomada apenas e tão somente pelo governo, deixar de realizar despesas não obrigatórias não constituía senão uma faculdade inerente aos poderes do Executivo. Se o Executivo se visse na iminência de realizar determinada política fiscal restritiva dos 
gastos, bastava-lhe bloquear a liberação dos recursos com fundamento nestas prerrogativas. O que a Lei de Responsabilidade Fiscal fez, porém, foi introduzir o dever de promover a limitação de empenho conforme a programação da execução financeira, referindo-se apenas a essa possibilidade. Negados tais poderes governamentais imanentes, a limitação de empenho afigura-se impossível fora dos casos de ajuste fiscal, porque não expressamente autorizada, na atual sistemática legal.

Sempre se poderia argumentar a esse respeito que tal restrição comprometeria o interesse público, por inviabilizar a necessária agilidade da parte do Executivo para responder a pressóes contingentes do ambiente econômico. Confrontado com passivos contingentes, porém, nada impede que o governo adote as medidas necessárias para conter gastos: isso é o que lhe impõe a Lei de Responsabilidade Fiscal. O que não se justifica, porém, é a decisão imotivada de deixar de cumprir os objetivos orçamentários sem que se tenha evidenciado algum risco à estabilidade econômica.

A questão que se depreende, então, é: A quem tal necessidade deve ser evidenciada? A qual crivo deve ser submetido a decisão do Executivo? Parece que exatamente ao Poder Legislativo, que aprovou não apenas a lei orçamentária, mas também a Lei de Diretrizes Orçamentárias e os Anexos nela contidos. Não obstante, esse controle fica reduzido a quase nada se tudo que o Poder Legislativo pode fazer é esperar o relatório da execução orçamentária para averiguar a decisão tomada pelo Poder Executivo. Em razão dessa dificuldade, são diversas as propostas que vêm abrigadas no rótulo do "orçamento impositivo".

\subsubsection{Dois casos: Alemanha e Estados Unidos}

A possibilidade de que o parlamento participe de decisões na fase de execução orçamentária não é, de modo algum, desconhecida, e se observa tanto em sistemas parlamentaristas como presidencialistas. O notável é que se trata de provisão encontrada em regimes orçamentários tão diversos como aqueles da Alemanha e dos Estados Unidos, em que por tantas vezes se observou a defesa mais consolidada das prerrogativas governamentais na execução orçamentária, ainda que essas formas de participação se apresentem com significativas distinções.

É comum que em orçamentos alemães se encontre o seguinte dispositivo em diversas dotações: "[a] anulação do bloqueio requer o consentimento da Comissão de Orçamento do Parlamento Alemão". ${ }^{241}$ Se na lei de orçamento enviada pelo

241 "Die Aufhebung der Sperre bedarf der Einwilligung des Haushaltsausschusses des Deutschen Bundestages" (cf. ALEMANHA. Entwurf eines Gesetzes über die Feststellung des Bundeshaushaltsplanes für das Haushaltsjahr 2011. Dispóe sobre o orçamento do exercício de 2011). 
governo algumas das despesas foram anotadas como suspensas (sperrvermerke), em alguns casos qualificados na própria lei é necessário o consentimento da Comissão de Orçamento do Parlamento para seu desbloqueio. O mecanismo se denomina contingenciamento qualificado (qualifizierte Sperrvermerke). Em outros casos, ainda, é preciso que haja duplo consentimento, tanto da Comissão de Orçamento como de outro comitê técnico parlamentar (doppelt qualifizierte Spervvermerke). ${ }^{242}$ O contingenciamento qualificado (e também o duplamente qualificado) conduz a que o Executivo, antes da liberação de recursos consentida pela Comissão de Orçamento, tenha que obter seu parecer e negociar politicamente. Tem-se, então, que um comitê parlamentar deve amparar decisóes governamentais técnicas, o que faz cair por terra o argumento puramente formal de que, como o orçamento constitui uma autorização, a decisão de gastar ou pertence à livre disposição do Executivo. ${ }^{243}$ Cabe, desse modo, à própria lei orçamentária definir quais as despesas que, por determinadas razões, não poderão ser conduzidas ou cuja execução não é obrigatória, especificando os casos em que se exigirá autorização de um ou mais comitês parlamentares para o levantamento da suspensão. ${ }^{244}$

Há, também, instituto semelhante ao da limitação de empenho brasileira: o contingenciamento por razões econômicas (hauswirtschaftliche Sperre), ${ }^{245}$ segundo o qual, se o comportamento das receitas ou das despesas assim o exigirem, cabe ao Ministério das Finanças, com o consentimento do ministro competente pela despesa, definir se o gasto pode ser executado. A Lei de Estabilidade, em vigor desde 1967, ainda define outra forma de bloqueio de recursos, de caráter conjuntural, para situações de aumento na demanda proveniente de superaquecimento econômico. Essa circunstância permite que o ministro das Finanças, com autorização do governo, tenha livre disposição sobre alguns recursos previstos no orçamento, o que quer dizer, especialmente, que o início de obras e a inclusão de futuras despesas obrigatórias em orçamentos seguintes dependam de seu consentimento. ${ }^{246}$ Embora, nesse caso, não se preveja a necessidade de autorização parlamentar, a prática

${ }^{242}$ Cf. MANDELARTZ, H. Das Zusammenwirken von Parlament und Regierung beim Haushaltsvollzug: ein Beitrag zum parlamentarischen Regierungssystem der Bundesrepublick Deutschland. Frankfurt a.M.: Peter D. Lang, 1980, p. 32-33.

243 MANDELARTZ, H. Das Zusammenwirken von Parlament und Regierung beim Haushaltsvollzug: ein Beitrag zum parlamentarischen Regierungssystem der Bundesrepublick Deutschland. Frankfurt a.M.: Peter D. Lang, 1980, p. 34.

$244 \$ 22$ BHO (Bundeshaushaltsordnung).

$245 \$ 41 \mathrm{BHO}$.

${ }^{246} \$ 1$ StabG (Stabilitätsgesetz) 
estabeleceu que esses contingenciamentos político-conjunturais devem ser autorizados pela Comissão de Orçamento. ${ }^{247}$

Finalmente, preveem-se também outras possibilidades de suspensão do gasto para obras em que as fundações ainda não foram concluídas. Interessante notar que, também nesses casos, a legislação faz referência apenas ao necessário consentimento do ministro das Finanças. Não obstante, a atuação da comissão parlamentar de orçamento tem sido mantida. ${ }^{248}$

Há fundamentações diversas para a previsão normativa de que o parlamento, ainda que tenha aprovado o orçamento, entenda que essa autorização não foi suficiente e é necessário que se manifeste novamente. A opinião esposada por Kewenig, de que o contingenciamento qualificado é previsto para os casos de relevantes implicações políticas, indica indubitavelmente um fator relevante. ${ }^{249}$ Entretanto, importante também é o fator temporal, muitas decisões relativas ao orçamento precisam ser tomadas em curto espaço de tempo. O projeto de orçamento precisa ser aprovado com relativa urgência, e decide-se postergar a discussão sobre determinadas dotações, levando-a a um momento futuro em que o orçamento está aprovado e vigente para outras matérias relevantes. $O$ parlamento pode, então, discutir com mais calma casos específicos de despesas, e para isso se prevê o contingenciamento qualificado. ${ }^{250}$ A aprovação orçamentária não significa, por si só, um laissez dépenser generosamente concedido ao governo, à medida que as matérias não completamente debatidas pela pressão do tempo têm sua discussão transferida para depois, marcando-se, assim, gastos que ainda merecem atenção e debate. O sistema parece bastante interessante em situações nas quais os parlamentares discutem efetivamente todas as políticas orçamentárias, e não apenas a parte relativa aos gastos para suas zonas eleitorais, ao mesmo tempo em que se preocupam com a viabilidade da política econômica ao não atrasar a entrada em vigor do orçamento em razão de dúvidas sobre dotações específicas. O contingenciamento é, portanto, uma decisão parlamentar, e a divisão do ciclo orçamentário em duas fases para o Poder Executivo e duas fases para o Poder Legislativo se mostra de pouco valor elucidativo.

247 MANDELARTZ, H. Das Zusammenwirken von Parlament und Regierung beim Haushaltsvollzug: ein Beitrag zum parlamentarischen Regierungssystem der Bundesrepublick Deutschland. Frankfurt a.M.: Peter D. Lang, 1980, p. 36.

$248 \$ 24$ Abs. 3 Satz 3 BHO.

249 KEWENIG, W. Staatsrechtliche Probleme parlamentarischer Mitregierung am Beispiel der Arbeit der Bundestagsausschüsse. Bad Homburg v.d.H.: Gehlen, 1970, p. 35.

${ }^{250}$ MANDELARTZ, cit., p. 37. 
O caso alemão indica a participação parlamentar na fase de execução orçamentária por meio da necessidade específica de que consinta, prévia e especificamente, com o pagamento de algumas despesas depois do orçamento aprovado. $\mathrm{O}$ fato de o governo decorrer do parlamento, e, portanto, a execução orçamentária ser, no limite, o exercício de uma competência conferida pelo Poder Legislativo, poderia indicar que essa forma de participação parlamentar na execução seria própria de sistemas parlamentaristas. $\mathrm{O}$ caso dos Estados Unidos, paradigma do sistema presidencialista, o desmente: mesmo a força da tradição do orçamento do Executivo culminou, após o governo Nixon, na necessidade de que o congresso aprove mesmo a decisão de não gastar. Isto é, a decisão de executar uma despesa abaixo do teto orçamentário.

Se o Presidente dos Estados Unidos decide gastar menos do que foi aprovado pelo congresso para uma despesa específica, há dois caminhos a seguir: ou esses gastos são cancelados ou atrasados. Tais ações, denominadas impoundments e que se assemelham aos contingenciamentos, eram tipicamente uma maneira de expressar a insatisfação presidencial com o trabalho do Legislativo. ${ }^{251}$ Isso mudou desde o Control Act de 1974, quando presidente e congresso passaram a ter atribuiçóes conjuntas na decisão de não gastar.

O contingenciamento orçamentário nos Estados Unidos representava um modo de contenção de recursos nas situações em que não fosse necessário gastar todo o volume de recursos previstos para determinada finalidade. Traduzia uma prática com a economia de recursos e a eficiência do gasto. Essa tradição, que tinha o significado profundo de um acordo tácito entre Executivo e Legislativo a propósito da inutilidade de se ter de recorrer a um moroso processo legislativo para tomar uma decisão positiva para as finanças públicas, começou a ser alterada durante o governo Nixon. Esse presidente tentou mudar a tradição de entendimentos informais, esforçando-se por inserir o contingenciamento no campo de prerrogativas presidenciais, que poderia gastar somente onde quisesse. ${ }^{252}$ Procedeu-se, a partir de então, a um massivo bloqueio de recursos. Schick ${ }^{253}$ formula-o com clareza:

251 WLEZIEN, C. The politics of impoundments. Political Research Quarterly, v. 47, n. 1, mar. 1994, p. 59.

252 WILDAVSKY; CAIDEN, cit., p. 74.

253 SCHICK, A. Congress and money. Washington: The Urban Institute, 1980, p. 46-8. No original: “[f]ar from administrative routine, Nixon's impoudments in late 1972 and 1973 were designed to rewrite national policy at the expense of congressional power and intent. Rather than the deferment of expenses, Nixon's aim was the cancellation of unwanted programs. (...) When Nixon impounded for policy reasons, He in effect told Congress, 'I don't care what you appropriate; I will decide what will be spent."” 
[1] onge de ser uma rotina administrativa, os contingenciamentos no final de 1972 e 1973 foram concebidos para reescrever a política nacional às custas dos poderes e intentos parlamentares. Em vez de postergar despesas, o objetivo de Nixon era o cancelamento de programas indesejados. (...) Quando Nixon realizou contingenciamentos por objetivos políticos, ele, na verdade, disse ao Congresso: "Eu não me importo com as suas dotaçōes; Eu decidirei o que será gasto".

Wildavsky e Caiden analisam que nenhum outro presidente havia tão diretamente ignorado as competências parlamentares sobre o orçamento, a não ser em casos emergenciais de guerra. Formularam, então, aquelas que parecem ser as mais decisivas questôes sobre a execução orçamentária em qualquer sistema ou regime de governo: Se o chefe do governo pode passar impune depois de contingenciamentos massivos, o que ele não pode fazer? Se o power of the purse for tão abertamente desafiado, o que sobra para o congresso?254

Nos Estados Unidos, as prerrogativas parlamentares sobre o orçamento tiveram que ser tão defendidas em 1974 como o foram em 1774. Mas pela razão oposta: duzentos anos antes, o congresso conquistara suas competências orçamentárias para se contrapor às ameaças de um Executivo que poderia gastar demais. O desafio contemporâneo, porém, era o de criar condições de contrabalançar o poder de um chefe de governo que quer gastar pouco e que desafia o Poder Legislativo (ou, como diriam os próprios parlamentares, o povo por ele representado). Os remédios, portanto, teriam que ser diferentes. A ênfase passaria a ser dada nos instrumentos parlamentares de participação na execução do orçamento, e não apenas na fase de elaboração, o que criou uma nova divisão de funções no ciclo orçamentário. $\mathrm{O}$ instrumento de tal alteração foi o Congressional Budget and Impoundment Act de 1974, que seguiu a tradição política americana de fazer uma espécie de "bricolagem" institucional, acrescentando novos procedimentos e instituições, reinterpretando as anteriores.

A formalização dos contingenciamentos presidenciais passou a depender de algumas etapas. Caso não deseje gastar o total dos fundos previstos para determinada despesa, o presidente necessita propor ao congresso a rescisão da dotação (rescission). Se, ao contrário, quiser apenas atrasar o gasto, deveria propor seu diferimento (deferral). O congresso deve aprovar a proposta de rescisão em até 45 dias. Se não o fizer, a proposta é considerada rejeitada - isto é, o dinheiro deve ser gasto como previsto no orçamento. O diferimento, a seu turno, tem efeitos automáticos a partir da decisão presidencial, mas não pode ultrapassar o exercício fiscal. A despeito disso, a qualquer tempo qualquer uma das casas parlamentares poderia rejeitá-lo

${ }^{254}$ WILDAVSKY; CAIDEN, cit., p. 74. 
em votação específica de desaprovação. Se o presidente não reportar ao congresso que não gastou o total dos recursos, o controlador-geral (chefe do General Accounting Office) deverá avisar o parlamento. A comunicação do controlador-geral tem o mesmo efeito jurídico da proposta presidencial de rescisão ou diferimento. Se o Presidente ignora a rejeição parlamentar, o controlador-geral é legitimado a propor uma ação civil judicial. É claro que sempre fica à disposição do Presidente a opção de provocar uma crise constitucional, o que é, no entanto, improvável. 255

Essas formas de participação parlamentar na execução orçamentária norte-americana têm sido especuladas constantemente como o réquiem do orçamento do Executivo: uma ideia ambígua exatamente em razão das dúvidas sobre a obrigatoriedade de gastar os montantes previstos no orçamento. Havia certa vagueza a respeito da posição do presidente como chefe do Executivo no sistema norte-americano de separação de poderes. ${ }^{256}$ Até o governo Nixon, o sistema havia servido, mas a contraposição frontal desse às competências parlamentares expôs todas as ambiguidades da relação entre administração pública e agenda política. A polarização entre um presidente republicano e um parlamento democrata rompeu a política de acomodação que havia a respeito dos gastos públicos. A fragilidade das concepções orçamentárias de 1921, com um congresso atuante, começou a ser exposta. ${ }^{257}$ Como bem destaca Pitsvada, ${ }^{258}$ "[p] residentes e congressos normalmente têm visões diferentes sobre as necessidades nacionais corporificadas nos programas e prioridades orçamentárias. Ambas as visões são legítimas e devem ser resolvidas mediante processo político em que o poder político conte mais que questões de eficiência administrativa."

Ficou perceptível que o contingenciamento de recursos como ato unilateral não ofereceu um procedimento nítido para resolver os impasses orçamentários entre os dois poderes, mas, ao contrário, incitou à sua paralisação e protraimento. ${ }^{259} \mathrm{~A}$ insuficiência do orçamento do Executivo como modelo de relações orçamentárias

255 Cf. WILDAVSKY; CAIDEN, cit., p. 75.

${ }^{256}$ CAIDEN, N. Paradox, Ambiguity, and Enigma: the Strange Case of the Executive Budget and the United States Constitution. In: RUBIN, I. (Ed.). Public budgeting: policy, process and politics. Nova York: ASPA Classis, 2008, p. 51.

257 CAIDEN, cit., p. 51.

${ }^{258}$ PITSVADA, B. T. The Executive Budget: an idea whose time has passed. In RUBIN, I. (Ed.). Public Budgeting: policy, process and politics. Nova York: ASPA Classis, 2008, p. 66. No original: "Presidents and Congresses often have differing views on national needs as embodied in budgetary programs and priorities. Both views are legitimate and must be resolved through the political process where political power counts more than questions of administrative efficiency."

259 SCHICK, cit., p. 48. 
entre governo e parlamento pode ser destacada na sua inaptidão para solucionar os conflitos entre visões políticas divergentes.

\subsubsection{O orçamento impositivo e a revisão das relações de poder}

No caso brasileiro, as competências orçamentárias do chefe do Executivo têm sido interpretadas, tradicionalmente, de maneira bastante ampla. Sob a orientação predominante de que o orçamento é uma autorização de gasto conferida irrevogavelmente no momento em que o parlamento o aprova, a execução orçamentária costuma ser compreendida como uma atividade em que gastar ou não gastar faz parte das prerrogativas governamentais.

Nota-se, porém, uma certa tendência: sucessivas propostas de emenda à Constituição e de alteração legislativa têm sido feitas para conferir ao Poder Legislativo instrumentos técnicos adequados para participar da decisão executória do orçamento. Seu produto é comumente denominado orçamento impositivo, ou um orçamento cujos montantes são de execução obrigatória. Com tais ideias, que não são uniformes e apresentam variações, não se pretende, evidentemente, excluir a atividade administrativa de execução da despesa do campo material de atividades do Poder Executivo, mas possibilitar ao parlamento maiores condições de determinar o poder que tem o governo de alterar uma política por ele decidida. A atividade administrativa governamental fica, desse modo, preservada, pois o que se observa nessas tentativas não é mais que dar maior eficácia à muito bem conhecida subordinação da administração à lei. Conferir maior eficácia à decisão política parlamentar, portanto.

A Lei de Responsabilidade Fiscal, ao estabelecer a necessária adequação do gasto às metas fiscais, criou uma forma de orçamento impositivo, pois a suspensão da despesa fica condicionada a uma única hipótese, que é a frustração do fluxo de receitas. Não obstante, essa interpretação deixa de prevalecer diante das facilidades com que se utiliza o contingenciamento de recursos para outros fins, como as negociações políticas com o Poder Legislativo. Em vista deste quadro, formularam-se diversas proposições para alterar a disciplina constitucional e legal do assunto.

Recebeu bastante destaque a Proposta de Emenda à Constituição (PEC) n. 22/2000, de autoria do senador Antônio Carlos Magalhães, aprovada pelo Senado e encaminhada à câmara como a PEC n. 565/2006. A ela será dada maior atenção, mas antes deve ser mencionado o conteúdo de outras iniciativas.

Partindo da câmara, a PEC n. 313/2000, de autoria do deputado Clementino Coelho, propôs a execução obrigatória das emendas parlamentares destinadas à 
saúde e à educação. Atualmente, encontra-se arquivada. Em 2001, foram duas as propostas de Emenda Constitucional n. 421/2001 (dep. Miro Teixeira) e n. 481/2001 (dep. Wellington Dias), as quais, respectivamente, propunham incluir na Constituição um dispositivo que tornaria o orçamento de execução obrigatória, a não ser quando o Congresso aprovasse solicitação presidencial para não gastar, e impedir que se suspendessem recursos destinados a emendas parlamentares. Por sua vez, a PEC n. 527/2002 (dep. Euler Morais) propóe que se estabeleçam percentuais mínimos de execução obrigatória das despesas. O Projeto de Lei Complementar (PLP) n. 87/2003 (dep. Reginaldo Germano) visa a alterar a Lei de Responsabilidade Fiscal, para que a LOA contenha projetos, designados na LDO, cujas dotaçôes devam ser obrigatoriamente executadas. Sem maiores sutilezas, a PEC n. 169/2003 (dep. Jaime Martins) torna o orçamento impositivo, conforme os planos anteriormente elaborados. O PLP n. 218/2004 (dep. Yeda Crusius) pretende alterar a LRF para tornar o orçamento impositivo, salvo caso de frustração da receita, caso em que caberia à $\mathrm{CMO}$ decidir definitivamente se o governo fica autorizado a não gastar. A PEC n. 385/2005 (dep. Marcondes Gadelha) também obriga à execução das emendas parlamentares, salvo aquelas cuja anulação foi previamente aprovada pelo Congresso. Finalmente, o PLP n. 15/2007 (dep. Onyx Lorenzoni) tem por objetivo tornar os gastos com segurança pública obrigatórios, reduzindo-se as despesas correntes em 0,1\% do PIB ao longo de dez anos.

Com início da tramitação no senado, a PEC n. 2/2000 (sen. José Alencar) propunha a execução obrigatória das emendas parlamentares. A PEC n. 28/2000 (sen. Pedro Simon e outros) obrigaria o presidente a enviar ao congresso mensagem em que constassem os créditos que não seriam totalmente gastos no exercício. Foi apensada à PEC n. 22/2000, que será considerada destacadamente em razão de sua importância. Em 2002, foi proposta a PEC n. 9 (sen. Marina Silva), que mudaria a organização da LOA, a qual passaria a compreender o orçamento fiscal, o orçamento social e o orçamento previdenciário. As despesas do orçamento social seriam de execução obrigatória. A PEC 24/2003 (sen. Paulo Paim) propôs a vedação do contingenciamento de recursos do orçamento da seguridade social. O Projeto de Lei do Senado Federal (PLS) n. 84/2006 (sen. Antônio Carlos Valadares), também sem maiores distinções e condições de flexibilidade, estabelece a execução obrigatória do orçamento, conforme a LDO. O PLS n. 134/2006 (sen. Álvaro Dias) propugnava a alteração da LRF para proibir a limitação de empenho de despesas destinadas à segurança pública, criando uma hipótese de crime de responsabilidade do Presidente da República no caso de seu descumprimento.

Muitas das propostas visavam, inicialmente, coibir as chamadas emendas parlamentares "guarda-chuvas", que deveriam ser mais bem especificadas de forma a 
atender um dos objetivos da programação. Quanto ao chamado orçamento impositivo, vislumbrava-se em algumas delas a possibilidade de obrigar o Poder Executivo a realizar o orçamento da maneira como foi aprovado pelo Poder Legislativo. $\mathrm{O}$ instrumento que seria utilizado para isso seria a necessidade de que o presidente da República tivesse que solicitar ao Congresso Nacional autorização para não gastar, total ou parcialmente, os recursos de determinada dotação, justificando a medida em termos econômicos, técnicos, operacionais ou jurídicos. Até aí, tudo pareceria o sistema norte-americano de contingenciamento de recursos, mas com diferenças específicas, como, por exemplo, a necessidade de que o pedido governamental fosse feito em até 120 dias antes do encerramento da sessão legislativa, e a previsão de que o silêncio parlamentar implicasse a aprovação automática da solicitação. O descumprimento da vontade parlamentar caracterizaria crime de responsabilidade por parte do presidente. Os prazos estabelecidos tampouco prevalecem no caso de frustração da receita ou de situações emergenciais (como guerras e calamidades públicas), quando a solicitação pode ser feita a qualquer momento.

Em relação às variações que as propostas de execução obrigatória das emendas parlamentares assumiram em sua fase de discussão parlamentar, o contraste do produto final é nítido. A mutação constitucional resultante configurou-se de forma distinta. Imediatamente decorrente da Proposta de Emenda Constitucional n. 358/2013, que ficou conhecida como a PEC do Orçamento Impositivo, a Emenda Constitucional n. 86, de 17 de março de 2015, alterou os arts. 165 e 1.655 da Constituição para fazer com que os recursos destinados pelas emendas parlamentares a projetos de seu interesse incluídos no orçamento não poderiam ter sua execução suspensa pelo Poder Executivo, salvo alguns impedimentos, tais como o descumprimento de metas de resultado fiscal. Pode-se dizer que essa emenda conferiu maior estabilidade à execução das emendas parlamentares, por meio da procedimentalização da forma de liberação de recursos. Previram-se limites máximos para o montante total das emendas em relação à receita corrente líquida prevista no projeto de lei orçamentária, assim como escusas constitucionais ao cumprimento da impositividade, diante de "impedimentos de ordem técnica” inerentes a qualquer fase de execução orçamentária. Essa necessária flexibilidade da execução exige agora, porém, a necessidade de justificativa para o contingenciamento dos recursos empenhados para as emendas, nos prazos constitucionalmente especificados, o que será feito por projeto de lei encaminhado pelo Executivo ao Legislativo, e não mais por ato administrativo próprio daquele Poder. Assim se configura o "orçamento impositivo à brasileira". ${ }^{260}$

260 A expressão é de SCAFF, F. F. Surge o orçamento impositivo à brasileira pela emenda constitucional 86. Revista Eletrônica Consultor Jurídico - CONJUR, publicada em 24 de março de 2015. 
O momento político de discussão de uma proposta com potencial para melhorar a qualidade da gestão orçamentária não foi suficientemente bem aproveitado em favor de uma medida que reforçasse as prerrogativas parlamentares gerais nas discussões orçamentárias; ao contrário, centrou-se na destinação de recursos a suas circunscriçôes eleitorais. Não que as emendas parlamentares sejam um problema em si. Ao contrário, potencialmente tais emendas poderiam ser um instrumento importante de democratizar a destinação de recursos públicos para atender a necessidades locais bem percebidas pelos seus representantes. Mas restringir o orçamento impositivo à questão das emendas na forma como elas estão configuradas não contribui para contornar uma dificuldade considerável do processo orçamentário brasileiro, que é a focalização dos debates parlamentares quase que exclusivamente em projetos de específico interesse local, e não em questões estruturantes de interesse nacional.

Cabe perguntar, então, se não haveria formas melhores de proceder a uma reforma de tal importância, sob o risco de passar-se a entender por "orçamento impositivo" apenas o conceito restrito positivado pela Emenda Constitucional n. 86, na forma da obrigatoriedade de execução das emendas parlamentares individuais. Uma transformação desse tipo envolve uma série de aspectos considerados a seguir sob os ângulos jurídico-político, referente à possibilidades constitucionais de atuação do Poder Legislativo na fase de execução do ciclo orçamentário e econômico, e econômico-financeiro, relacionado às características peculiares das finanças públicas brasileiras que condicionam as possibilidades e os objetivos de uma reforma orçamentária.

Sob um ponto de vista jurídico-político, trata-se de estender à limitação de empenho e movimentação financeira alguma forma de participação parlamentar que existe com relação a outros instrumentos de flexibilidade orçamentária. É a Constituição Federal, dessa forma, que prevê a necessidade de autorização parlamentar para a abertura de créditos adicionais ou sua ratificação, bem como para a transferência de recursos entre dotações orçamentárias. A participação do Poder Legislativo na execução orçamentária existe na ordem jurídico-orçamentária brasileira. O que se pretende com o chamado orçamento impositivo é ampliar essa atuação conjunta também à decisão governamental de não gastar, na qual se observa com nitidez a extensão dos poderes atribuídos ao Poder Executivo - poderes que, dada a própria disciplina constitucional da execução orçamentária, podem ser reduzidos, criando-se restrições para os gastos abaixo do teto que existem em outras decisões executórias do orçamento.

A maneira como se distribui a competência decisória sobre o dinheiro público faz parte de combinações institucionais de maior abrangência. Muito se pode questionar 
para além da viabilidade jurídica ou do sentido constitucional da medida. O poder acachapante do presidente da República, do qual o poder financeiro é uma das maiores expressões, tem implicações políticas de monta, e não é exagerado supor que uma mudança substancial nas relações entre os poderes na fase de execução orçamentária significaria um rearranjo institucional historicamente significativo. Que o congresso brasileiro tivesse o mesmo grau de participação na decisão de execução do orçamento que tem o norte-americano, é algo que dependeria de condiçóes objetivas no campo político. A viabilidade do orçamento impositivo impõe considerar algumas alterações nas relações de poder.

É possível imaginar que como uma decisão unilateral passaria a ser negociada o Executivo veria seu poder de barganha enfraquecido, ao passo que o Poder Legislativo se fortaleceria. A prática da liberação ou bloqueio de recursos antes de votações importantes do Congresso tenderia a ser modificada. ${ }^{261}$ A oposição também seria beneficiada, pois haveria maiores dificuldades para que o Executivo liberasse discricionariamente recursos para obras locais de acordo com o apoio manifestado pelo parlamentar. As emendas individuais poderiam ser implementadas independentemente do partido do autor, pois todos os parlamentares, atualmente, recebem uma quantidade fixa de recursos. Paralelamente, as vantagens que os parlamentares da situação têm em relação a parlamentares da oposição se veriam diminuídas. Um orçamento impositivo, desse modo, "não seria neutro dentro do parlamento". ${ }^{262}$ A instituição parlamentar como um todo atingiria um grau de participação no processo orçamentário, ao menos em sua potencialidade, nunca anteriormente alcançado. Esse quadro permite antever dificuldades fundamentais para alterações com essa profundidade nas relações de poder entre Executivo e Legislativo, bem como entre governo e oposição: Por que aqueles que se beneficiam do atual modelo de execução orçamentária se esforçariam para alterá-lo?

Encontra-se na literatura, ainda, a dúvida a respeito do esforço da opinião pública e da pressão social para uma alteração desse tipo, ainda que se trate de um problema diacrônico no Brasil. O hermetismo da linguagem e o fato de os ganhos não serem imediatamente perceptíveis para a população, como ocorreria com a reforma tributária ou previdenciária, fazem com que a discussão sobre uma reforma

261 Para uma análise detalhada sobre o funcionamento do orçamento público como instrumento de barganha, cf. PEREIRA, C.; MÜLLER, B. Comportamento estratégico em coalizões presidenciais: as relações entre Executivo e Legislativo na elaboração do orçamento brasileiro. Dados, Rio de Janeiro, v. 5, n. 2, 2002.

${ }^{262}$ LIMA, E. C. P. Algumas observaçōes sobre orçamento impositivo no Brasil. Planejamento e Políticas Públicas-PPP, Brasília, n. 26, 2003, p. 11. 
orçamentária não encha a praça e fique restrita a especialistas. ${ }^{263} \mathrm{~A}$ mobilização social pela construção de maiores prerrogativas parlamentares na execução orçamentária parece difícil de antever, com certo grau de realismo. Em um cenário em que pesquisas de opinião apontam o descrédito com o Congresso Nacional, cuja aprovação social é menor que a do governo ou da figura pessoal do Presidente da República, a legitimidade de uma mudança que favorecesse o Legislativo em detrimento do Executivo pode ser questionada. Há dificuldades políticas de peso, portanto, para uma reforma da execução orçamentária.

Não é possível perder de vista, ainda, que diversas das características atuais da execução orçamentária existem também em razão de disfunções das finanças públicas. O sistema orçamentário brasileiro apresenta uma série de inconsistências que poderiam ser agravadas com a obrigatoriedade de execução dos montantes orçamentários, fosse essa medida implementada isoladamente. Um orçamento composto em sua grande parte de despesas obrigatórias, que o tornam bastante rígido, acantona as possibilidades de uma política fiscal eficiente ao corte da parte discricionária dos gastos públicos, identificada predominantemente com os investimentos. São esses que oferecem possibilidades de corrigir desequilíbrios fiscais pelo corte de despesas, dadas as dificuldades de cortar gastos fixos. De outro lado, quanto ao aumento da receita, o sistema tributário brasileiro produz fortes incentivos para que o governo federal aumente sua arrecadação utilizando-se das contribuições, não repartidas entre os entes da federação. A vinculação das contribuições à seguridade social foi parcialmente contornada com a Desvinculação de Receitas da União (DRU), segundo a qual $20 \%$ das receitas vinculadas podem ser manejadas para outros fins. Os outros $80 \%$, porém, ficam referidos a um fim específico. A rigidez orçamentária, assim, gera uma dificuldade de ordem estrutural: a geração de superávits orçamentários por meio do aumento das contribuiçôes faz com que cresçam simultaneamente as vinculações. O financiamento do superávit tende, nesse modelo, a aumentar a rigidez do orçamento. Em um momento seguinte, porém, para continuar a política do superávit é necessário aumentar ainda mais as contribuiçõos, em uma situação em que se torna extremamente difícil recuar. Esse efeito, batizado de "efeito cremalheira", é acompanhado ainda de outro, o "efeito bumerangue". Para atenuar o impacto do crescimento de despesas obrigatórias, a saída é impor restriçõoes aos gastos na execução orçamentária, promovendo contingenciamentos e transferências para exercícios seguintes, mediante os restos a pagar. A baixa qualidade da gestão orçamentária, que na prática acaba se voltando para garantir condições de formação de superávit, e não a consecução de políticas e

263 REZENDE, F. A reforma orçamentária e a eficiência fiscal. Brasília: Ipea, 2009, p. 29 e ss. 
programas orçamentários, decorre de problemas mais amplos das finanças públicas a serem resolvidos, aqui apenas delineados. Parte do problema da flexibilidade, pois, se origina no excesso de rigidez do orçamento. ${ }^{264}$

Isso não deve, em si, impedir a ampliação dos poderes parlamentares na execução orçamentária, pois não se deve entender que os mecanismos para alteração do orçamento ficariam extintos com a criação do orçamento impositivo. Um orçamento impositivo radicalizado a esse ponto seria certamente pernicioso, e as possibilidades de ajuste fiscal devem ser mantidas. Isto é, no mais, previsto pela LRF, que vincula o contingenciamento ao cumprimento de metas fiscais. É inegável, porém, que restriçôes ao contingenciamento de recursos devem levar em consideração a importância que eles adquiriram para a gestão macroeconômica do país. Nesse sentido, uma reforma orçamentária deve ser amplamente compreendida. Todo seu potencial para conferir maior qualidade às finanças públicas depende não só da construção de instrumentos para assegurar o cumprimento dos programas orçamentários, favorecendo o planejamento, mas também para garantir a racionalização do orçamento no Estado brasileiro, que habitualmente recorre à vinculação de receitas, ao artifício dos restos a pagar, ao desvio de finalidade dos programas, dentre outras práticas. $\mathrm{O}$ orçamento impositivo deve ser pensado como mais uma das modificações necessárias nas finanças públicas, que, entretanto, não são poucas e demandam uma solução articulada.

264 A descrição de ambos os efeitos é amplamente descrita em REZENDE, F. A reforma orçamentária e a eficiência fiscal. Brasília: Ipea, 2009, p. 9 e ss. 
